\title{
Results from Tank 48H Slurry Decontamination and Decomposition Experiments in Support of ITP Process Verification Testing
}

by

D. D. Walker

Westinghouse Savannah River Company

Savannah River Site

Aiken, South Carolina 29808

C. A. Nash

DOE Contract No. DE-AC09-89SR18035

This paper was prepared in connection with work done under the above contract number with the U.S.

Department of Energy. By acceptance of this paper, the publisher and/or recipient acknowledges the U. S. Government's right to retain a nonexclusive, royalty-free license in and to any copyright covering this paper, along with the right to reproduce and to authorize others to reproduce all or part of the copyrighted paper. 
This report was prepared as an account of work sponsored by an agency of the United States Government. Neither the United States Government nor any agency thereof, nor any of their employees, makes any warranty, express or implied, or assumes any legal liability or responsibility for the accuracy, completeness, or usefulness of any information, apparatus, product, or process disclosed, or represents that its use would not infringe privately owned rights. Reference herein to any specific commercial product, process, or service by trade name, trademark, manufacturer, or otherwise does not necessarily constitute or imply its endorsement, recommendation, or favoring by the United States Government or any agency thereof. The views and opinions of authors expressed herein do not necessarily state or reflect those of the United States Government or any agency thereof.

This report has been reproduced directly from the best available copy.

Available to DOE and DOE contractors from the Office of Scientific and Technical Information, P. O. Box 62, Oak Ridge, TN 37831; prices available from (423) 576-8401.

Available to the public from the National Technical Information Service, U. S. Department of Commerce, 5285 Port Royal Road, Springfield, VA 22161. 


\section{DISCLAIMER}

Portions of this document may be illegible in electronic image products. Images are produced from the best available original document. 
WESTINGHOUSE SAVANNAH RIVER COMPANY SAVANNAH RIVER TECHNOLOGY CENTER

WSRC-TR-96-0190

Keywords: In-tank process, flammability, benzene, tetraphenylborate

Retention time: permanent

September 6, 1996

TO: S. D. FINK, 773-A

FROM : $\quad$ D. D. WALKER, 773-A, and C. A. NASH, 676-1T

RESULTS FROM TANK 48H SLURRY DECONTAMINATION AND DECOMPOSITION EXPERIMENTS IN SUPPORT OF ITP PROCESS VERIFICATION TESTING (U)

Authors
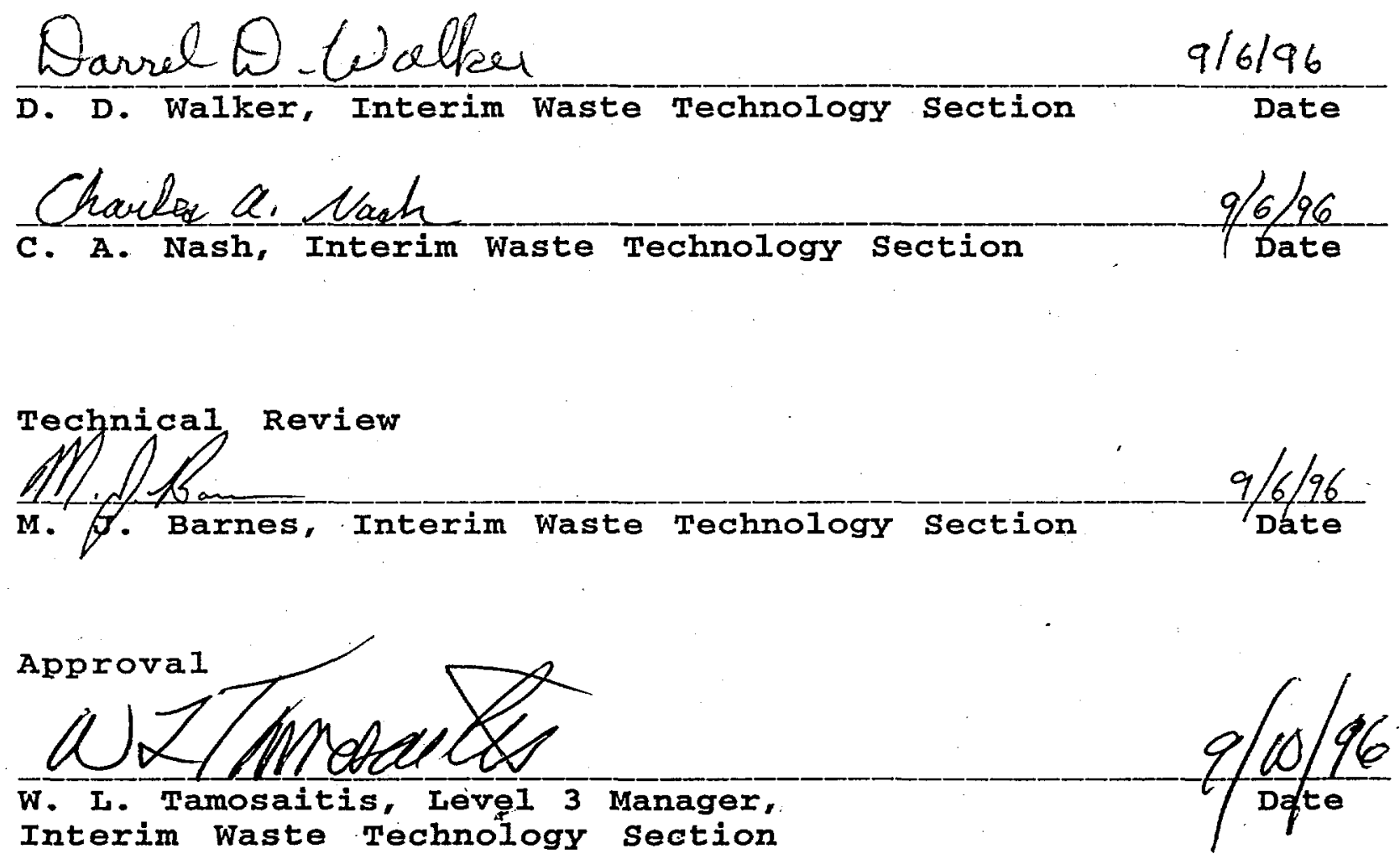
WSRC-TR-96-0190

Page 2 of 35

September 6, 1996

\section{Summary}

Addition of sodium tetraphenylborate (NaTPB) to Tank $48 \mathrm{H}$ will reduce the soluble Cs-137 concentration to below $12 \mathrm{nCi} / \mathrm{g}$, well within the pending Process Requirement limit of $85 \mathrm{nCi} / \mathrm{g}$. Addition of 175 gallons of 0.55 molar NaTPB solution to Tank $48 \mathrm{H}$, as proposed for the Process Verification Testing Phase 1 (PVT-1), will achieve this level of decontamination. Neither the source of the NaTPB (Tank $49 \mathrm{H}$ or vendor supplied solution) nor the presence of organic decomposition products currently in Tank $48 \mathrm{H}$ affect the decontamination.

Excess sodium tetraphenylborate in Tank $48 \mathrm{H}$ is susceptible to decomposition and the rate is strongly influenced by temperature. Limiting Tank $48 \mathrm{H}$ to $40{ }^{\circ} \mathrm{C}$ slows the rate by an order of magnitude relative to $50{ }^{\circ} \mathrm{C}$. At the slow decomposition rates measured at $40{ }^{\circ} \mathrm{C}$ and with an initial soluble NaTPB concentration of $100 \mathrm{mg} / \mathrm{L}$ (obtained by addition of 175 gallons of 0.55 molar NaTPB solution), the decontamination of the salt solution is maintained for ten days or longer. At the fast rates measured at $50{ }^{\circ} \mathrm{C}$, the excess NaTPB decomposes in less than two days.

After the excess NaTPB decomposes, the soluble Cs-137 level increases. As measured in laboratory tests, the initial rate of increase can be very rapid ( $>100 \mathrm{nCi} / \mathrm{mL} /$ day), but slows within a few days. This phenomena was not observed in Tank 48H, where a constant rate of increase $(1.4 \mathrm{nCi} / \mathrm{mL} /$ day) has been measured for over nine months. The Cs-137 increase is due to decomposition of a small amount potassium and cesium tetraphenylborate solids (KTPB and CsTPB). The largest increases in soluble Cs-137 measured in laboratory experiments correspond to decomposition of 0.05 to $0.5 \%$ of the solids.

Further work is required to fully understand the decomposition of the excess NaTPB. Some test results imply that rapid decomposition occurs at temperatures lower than $50^{\circ} \mathrm{C}$. Also, the factors affecting the decomposition rate of the solids are not known. Suggestions for further studies in these areas are presented.

\section{Introduction}

The In-Tank Precipitation (ITP) process started radioactive operations in Tank $48 \mathrm{H}$ in August 1995. Three months later, the excess sodium tetraphenylborate (NaTPB) in the tank decomposed at a rate more rapid than expected from prior experience and testing. ${ }^{1}$ The decomposition has necessitated deferring full production in ITP until additional Process Verification Tests (PVT-1, PVT-2, etc.) complete. ${ }^{2}$ These tests include laboratory experiments with high level waste slurries in the SRTC Shielded Cells Facility. The purpose of the Shielded Cells testing is to demonstrate the changes that occur from chemical additions to the slurry in Tank 48H. In particular, the tests should provide information on Cs-137 decontamination, the rate of decomposition of NaTPB, the rate of 
WSRC-TR-96-0190

Page 3 of 35

September 6, 1996

increase in Cs-137 following loss of NaTPB, and the rate of production of benzene and other decomposition products.

The PVT plan changed several times during its development, but always included two phases. The first phase (PVT-1) adds a small amount of NaTPB to Tank $48 \mathrm{H}$ to demonstrate the precipitation of soluble Cs-137 and to measure the rate at which the excess NaTPB decomposes. The original plan was to add Tank $49 \mathrm{H}$ salt solution, which contains residual NaTPB from the 1983 full-scale

demonstration. However, due to concerns about the transfer route from Tank $49 \mathrm{H}$ to Tank $48 \mathrm{H}$, the plan changed to add NaTPB from drums of solution prepared by Holley Oak Chemicals. The second phase (PVT-2) adds fresh waste, dilution water, Tank $49 \mathrm{H}$ salt solution, and additional NaTPB solution from Holley Oak Chemicals.

The results of the demonstration tests to support PVT-1 are reported below. Decomposition of tetraphenylborate and increases in soluble Cs-137 were observed and several of the factors suspected of affecting rates have been examined. The results to date do not provide an adequate understanding of the phenomena and further work is suggested.

\section{Identification of Experiments}

The experiments completed in support of this program have been numbered to simplify identifying them in the following discussions. Table I provides this numbering system with a brief description of the major features of each experiment. This numbering system is used consistently in all of the tables in this report and in other reports referring to these results." Chronologically, Experiments \#1 through \#4 were performed in the sequence in which they are numbered. Experiments \#5 and \#6, although performed earlier than $\# 1-\# 4$, are included at the end of the list because they used quite different protocols and the results are not directly comparable to Experiments \#1-4. The results, however, have been widely discussed and are included here for completeness.

\section{Precipitation of Cs-137}

Decontamination of the supernate in Tank $48 \mathrm{H}$ slurries has been demonstrated in several experiments. The results support the following conclusions.

- Precipitation of Cs-137 occurs within 2-4 hours of adding excess NaTPB.

- Soluble Cs-137 is reduced to less than $12 \mathrm{nCi} / \mathrm{mL}$ with excess $\mathrm{TPB}^{-}$concentrations less than $150 \mathrm{mg} / \mathrm{L}$.

- Neither the source of the NaTPB nor the organic decomposition products currently found in Tank $48 \mathrm{H}$ significantly affect decontamination. 


\section{TABLE I. Summary of Experiments}

\begin{tabular}{|c|c|c|c|c|c|c|c|c|c|c|c|c|c|c|c|}
\hline \multirow{4}{*}{ Test } & st'Experiment & Result & Initial & Soluble & Solids & Temp & Date of & NaTPB & Initial & Solids & Vessel & $\mathrm{Na}+$ & Inltial & Initial & Iest \\
\hline & $\ldots$ & 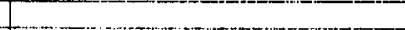 & Rate of Loss & Cs.137 & Decomp. & $\left({ }^{\circ} \mathrm{C}\right)$ & Sample & source: & Excess & (wt \%) & sype" & $(M)$ & IPBt & Phenol & \multirow{2}{*}{$\frac{\text { Duration }}{\text { iddays) }}$} \\
\hline & . & & of TPB. & $(\mathrm{nc} 1 / \mathrm{mL})$ & (wt \%) & & From & & NaTPB & & & & $(\mathrm{mg} / \mathrm{L})$ & $(\mathrm{mg} / \mathrm{L})$ & \\
\hline & & & (mg/L/day) & & & & TK 48H & & $(\mathrm{mg} / \mathrm{L})$ & & & & & & \\
\hline 1 & Cs.137 Decontamination Test & Cs.137 reprecipitated & NAtt. & NA. & NA & $27 \pm 5$ & $5 / 8 / 96$ & TK $49 \mathrm{H}$ & varled & NA & poly. & 3.7 & NA & NA & \\
\hline & TPB. Decomposition Test & rapid loss of TPB. $(24 \mathrm{hr})$ & $>54$ & 534 & 0.1 & $39 \pm 8$ & $2 / 96$ & $\mathrm{~K} 49 \mathrm{H}$ & 128 & 3.7 & ss & 3.7 & 461 & 1271 & \\
\hline & with TK 49H NaTPB & Cs. 137 jumped to $534 \mathrm{nCl} / \mathrm{mL}$ & & aiter 1 day & & & $5 / 8 / 96$. & & & & & & & & \\
\hline \multirow[t]{2}{*}{$3 A$} & TPB. Decomposition Test & no significant loss of TPB- & stable & 5.5 & $<.001$ & $39 \pm 8$ & $6 / 28 / 96$ & TK 49H & 93 & 0.8 & ss & 3.5 & 152 & 1244 & \\
\hline & at Low WL \% Solids & - & & after 8 days & & & & s. & & & & & & & \\
\hline \multirow[t]{2}{*}{ 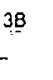 } & $\begin{array}{l}\text { TPB. Decomposition Test } \\
\text { Effect of 2nd Batch Dilution }\end{array}$ & no significant loss of TPB. & stable & & $<.001$ & $39 \pm 8$ & $6 / 28 / 96$ & AFF/AG & 5,000 & 0.8 & cs & 4.7 & 69 & 406 & 8 \\
\hline & & & & & & & & & & & & & & & \\
\hline 30 & $\begin{array}{l}\text { Continuation of E3A } \\
\text { â Higner Temperature }\end{array}$ & fapid loss of TPB. & 29 & 11.8 & $<.01$ & $46 \pm 10$ & $6 / 28 / 96$ & TKk $49 H$ & 144 & 0.8 & ss & $\overline{3}$ & $12 ?$ & .1333 & \\
\hline \multirow[t]{2}{*}{$3 \ddot{E}$} & 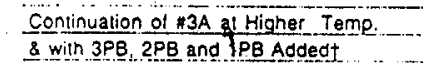 & Iapid loss of IPB. & 49 & 8.9 & $<.01$ & $46 \pm 10$ & $6 / 28 / 96$ & $T K 49 \mathrm{H}$ & 29661 & 10.8 & iss & 3.5 & 922 & .1442 & . \\
\hline & & & & & & & & & & & & & & & \\
\hline $4 \mathrm{~A}$ & TPB. Decomposition Test & slow loss of TPB. & 5 & 32.1 & $<.01$ & $40 \pm 5$ & 7114196 & $H O C$ & 94 & 4.0 & iss & 3.5 & $\underline{93}$ & 1164 & $\ldots . i 4$ \\
\hline \multirow[t]{2}{*}{$4 B$} & Duplicate of $\# 4 A$ & Slow loss of TPB. & 5 & 24,2 & $\leq \leq 01$ & $40 \pm \underline{5}$ & $7 / 14 / 96$ & $\mathrm{HOC}$ & 103 & 4.0 & cs. & 3.5 & 102 & 9181 & \\
\hline & 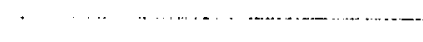 & - & F...... & after 14 days & & 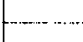 & 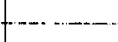 & $x^{2}+2$ & $\cdots$ & & & $\therefore$ & & & \\
\hline \multirow[t]{2}{*}{$4 c$} & Continuation of $\# 4 A$ & rapid loss of TPB. & 63 & $4,7 \quad \ldots$ & $<.001$ & $52 \pm 4$ & $7 \longdiv { 1 4 / 9 6 }$ & $\mathrm{HOC}$ & 282 & 4.0 & jes & 3.5 & 119 & $\overline{399}$ & $-\quad \ldots \ldots 2$ \\
\hline & at Higher Temperature & & $\cdots-1$ & atter 2 days & & & & & & & 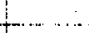 & & & & \\
\hline \multirow[t]{2}{*}{40} & Continuation of $\mathrm{H} 4 \mathrm{~B}$ at Higher Temp. & rapid loss of TPB. & 60. & $222 \ldots \ldots$ & 0.05 & $52 \pm 4$ & $7 / 14 / 96$ & HOC & 188 & 4.0 & cs. & 3.5 & 334 & .1579. & $\underline{5}$ \\
\hline & $\therefore$ with $3 P B$ and $2 P B$ Addedt & Cs.137 lumped to $222 \mathrm{nCl} / \mathrm{mL}$ & & after 5 days & & & & & & & & & & & \\
\hline \multirow[t]{2}{*}{$?$} & PQB. Decomposition Test & rapio loss of TPB. & $\geq 700$ & 2550 & 0.5 & $50 \pm 5$ & $12 / 18 / 95$ & AFF/Ag & 17,000 & 5,1 & poly & 4.7 & 1980 & 1073 & 73 \\
\hline & with AFFAA NaTPB (early experiment). & large increase in soluble Cs.137. & & alter16 days & & & & & & & & & & & \\
\hline \multirow[t]{2}{*}{0} & New Bateh Simulation Test & ss of TPB. & stable & 24 & $<.00 t$ & $50 \pm 5$ & $1 / 21 / 96$ & $T K 49 \mathrm{H}+\mathrm{AFF} / \mathrm{Ag}$ & 10,000 & 2.3 & poly & 5.0 & $600+t$ & $250+t+$ & 73 \\
\hline & $\frac{\text { with } T K 25 F \text { and } T K}{\text { (early experiment) }}$ & & -1 & atter 11 & & & & & & & & & & & (n) \\
\hline
\end{tabular}

* The three sources of sodium tetraphenylborate are:

Tank $49 \mathrm{H}$ : Salt solution from Tank $49 \mathrm{H}$ which contain

residual NaTPB from the 1983 full scale In-Tank

Precipitation demor

AFF/Aq: Representative composite sample from the truckloads

of. AFF/Aquafine NaTPB solutions added to Tank $48 \mathrm{H}$

HOC: Solution prepared by Holley oak Chemicals from AFF

NaTPB that had been spray dried by Aquafine. This

batch was identified as the probable source of This

for the PVT-1 plant test.

** poly $=$ polyethylene; $\mathbf{s s}=$ stainless steel; $\mathrm{cs}=$ carbon steel

1PB $=$ phenylboronic acid, $\left(\mathrm{C}_{6} \mathrm{H}_{5}\right) \mathrm{B}(\mathrm{OH})_{2}$

$2 \mathrm{~PB}=$ diphenylborinic acid $\left(\mathrm{C}_{6} \mathrm{H}_{5}\right)_{2} \mathrm{BOH}$

$3 \mathrm{~PB}=$ triphenylboron $\left(\mathrm{C}_{6} \mathrm{H}_{5}\right)_{3} \mathrm{~B}$

1 NA = not available

111 Corrected for dilution. 


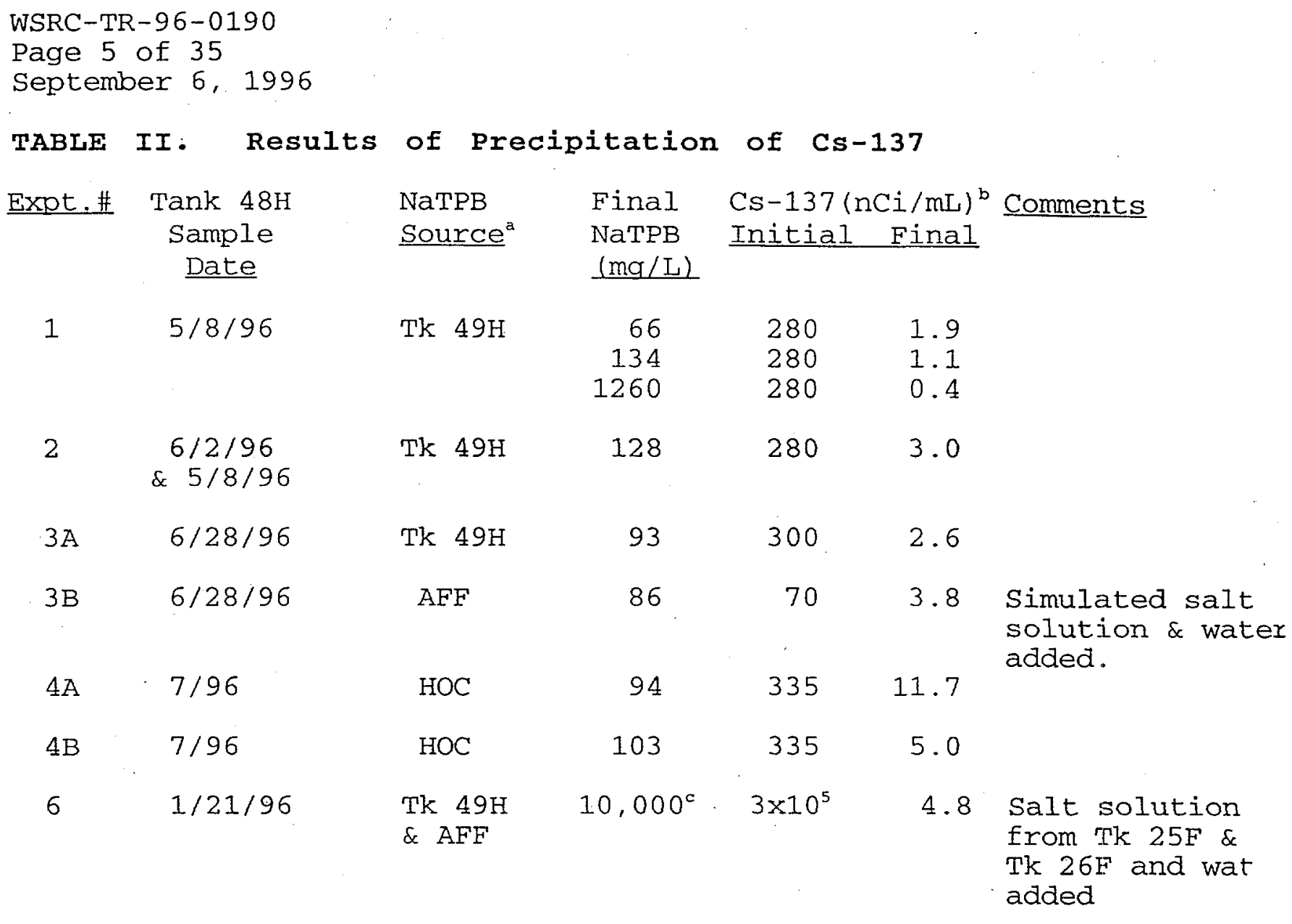

a Tank 49H solution was a composite of several dip samples taken $4 / 96$ and the $\mathrm{TPB}^{-}$concentration was $0.023 \mathrm{M}$. AFF solution was 0.55 $M \cdot N a T P B$ and was the same material that was added to Tank $48 \mathrm{H}$ in August 1995. HOC (Holley Oak Chemicals) solution was $0.59 \mathrm{M}$ NaTPB intended for use in the PVT-1 test. These solutions are described further in Appendix A.

${ }^{b}$ Note that the values listed are in units of $\mathrm{nCi} / \mathrm{mL}$. If expressed as $\mathrm{nCi} / \mathrm{g}$ (as is usual when referring to the saltstone process limits), the values would be 10-20\% lower.

c Includes insoluble NaTPB.

Table II lists the results from several experiments and further details are given in Appendix A. In all of the experiments, the NaTPB was added to Tank $48 \mathrm{H}$ slurry or a mixture of Tank $48 \mathrm{H}$ slurry with other salt solutions, stirred for 2 to 4 hours at ambient temperature, and filtered through a nominal 0.45 micron pore size filter.

In these experiments, the final Cs-137 concentration varied in the range 0.4 to $12 \mathrm{nCi} / \mathrm{mL}$. Variations in this range are unimportant to the process since the acceptable limit is much higher. The variations are probably due to differences in slurry composition, excess NaTPB, temperature, mixing, length of time before sampling, and small random errors in sampling and analysis. 
WSRC-TR-96-0190

Page 6 of 35

September 6, 1996

The effect of excess NaTPB was examined in the first experiment (Table II), where incremental amounts of Tank $49 \mathrm{H}$ salt solution were added to Tank $48 \mathrm{H}$ slurry to determine the amount required to precipitate the potassium and Cs-137. As expected, increasing the excess soluble tetraphenylborate decreases the soluble Cs-137. Adequate decontamination was achieved with as little as $66 \mathrm{mg} / \mathrm{L} \mathrm{TPB}$ in solution. However, for reasons cited above, the exact concentration of soluble Cs-137 is variable ( 0.4 to $11.7 \mathrm{nCi} / \mathrm{mL}$ ) when the soluble $\mathrm{TPB}^{-}$is in the range 66 to $134 \mathrm{mg} / \mathrm{L}$.

Efficient decontamination was achieved using tetraphenylborate from either Tank 49H, AFF/Aquafine, or Holley Oak Chemicals. Also, the organic decomposition products currently in Tank $48 \mathrm{H}$ do not prevent acceptable decontamination provided excess NaTPB is present. The levels of phenol and phenylboronic acid $\left[\left(\mathrm{C}_{6} \mathrm{H}_{5}\right) \mathrm{B}(\mathrm{OH})_{2}\right)$ or $\left.1 \mathrm{~PB}\right]$ are shown in Table I. Phenol varied between 250 and $1579 \mathrm{mg} / \mathrm{L}$; $1 \mathrm{~PB}$ varied between 69 and $922 \mathrm{mg} / \mathrm{L}$.

\section{Decomposition of Soluble Tetraphenylborate}

The rate of decomposition of NaTPB in Tank $48 \mathrm{H}$ slurry samples has been measured in several experiments in the SRTC Shielded Cells. The results show the following.

- The rate of the decomposition reaction increases significantly with temperature between 40 and $50{ }^{\circ} \mathrm{C}$. In general, the rate of decomposition is slow at $40{ }^{\circ} \mathrm{C}(0-5 \mathrm{mg} / \mathrm{L} /$ day $)$ and fast at $50{ }^{\circ} \mathrm{C}$ (34 to $63 \mathrm{mg} / \mathrm{L} /$ day).

- There appears to be a correlation between the rate of loss of TPB $^{-}$and the weight percentage of Tank $48 \mathrm{H}$ solids present in the slurry. This result implies that the solids either contain a catalyst (for example, heavy metals in the sludge portion of the solids), or provide a medium for the reaction (for example, the surface area of the KTPB particles).

- The following factors do not show a correlation to the rate of decomposition:

- concentrations of decomposition products (1PB and phenol)

- the source of NaTPB,

- the materials of construction of the reaction vessels,

- the date the Tank $48 \mathrm{H}$ slurry was taken, or

- the concentration of the salt solution.

The experimental conditions and results are given in Table I. For. most experiments, the soluble Cs-137, NaTPB, 1PB, and phenol concentrations were measured over a period of time while the slurry was held at temperature. Graphs of these concentrations, detailed descriptions, and data are given in Appendix $A$. 
WSRC-TR-96-0190

Page 7 of 35

September 6, 1996

The decomposition of excess NaTPB can be followed by measuring the $\mathrm{TPB}^{-}$concentration in filtrate samples. As long as measurable amounts of $\mathrm{TPB}^{-}$are present in solution (>50 $\left.\mathrm{mg} / \mathrm{L}\right)$, the soluble Cs-137 concentration remains $10 \mathrm{w}(0.1$ to $12 \mathrm{nCi} / \mathrm{mL})$. The concentration of soluble Cs-137 should increase as the TPB concentration decreases. However, due to reasons cited in the discussion of decontamination, the trend is not always discernable above the random variations in the data. Nevertheless, the data within some experiments does show a slight upward trend in soluble Cs-137 as the TPB ${ }^{-}$concentrations decreases (for instance, see the data from Experiment \#4 in Appendix A).

When the decomposition of soluble TPB is complete, then the soluble Cs-137 concentration in filtrate increases. In Tank 48H, the rate of increase has been constant at approximately $1.4 \mathrm{nCi} / \mathrm{mL}$ per day since early December 1995. ${ }^{1}$ Since an increase in soluble Cs-137 indicates decomposition of the solid tetraphenylborate compounds in the slurry, and since the solids are largely potassium tetraphenylborate, the increase in Cs-137 is accompanied by an increase in soluble potassium ion. This correlation has been observed in Tank 48H. The organic decomposition products (1PB, phenol, and benzene) may also indicate the extent of reaction of TPB', although they are not as sensitive a measure as the changes in TPB and Cs-137. This is especially true of Tank 48H slurries that already have large amounts of the other organics present. A small. change in $\mathrm{TPB}^{-}$will not produce enough $1 \mathrm{~PB}$ or phenol to create a detectable change in their concentrations.

The rate of decomposition of TPB $^{-}$can be estimated from the results of eight experiments (\#2, \#3D, \#3E, \#4A, \#4B, \#4C, \#4D and \#5), but not from three that appeared stable (\#3A, \#3B, and \#6). The initial rates of loss TPB are listed in Table $I$. Note that this is an approximate method of comparing the results from different experiments. A more rigorous analysis of the data, using rate constants for the reactions, appears in a separate report. ${ }^{4}$ However, the initial rate of loss is used for qualitative comparisons in the following discussions.

Two experiments (Table'I, Expt.\#2 and \#5) present problems in estimating the initial rate of $\mathrm{TPB}^{-}$decomposition. In Experiment \#2, the $\mathrm{TPB}^{-}$concentration was $74 \mathrm{mg} / \mathrm{L}$ after 1 day, the soluble Cs-137 concentration was $534 \mathrm{nCi} / \mathrm{mL}$, and the soluble potassium ion concentration was $7 \mathrm{mg} / \mathrm{L}$. The presence of all three in solution is contradictory since all other work indicates that the Cs-137 and potassium should precipitate if soluble $\mathrm{TPB}^{-}$is present. It is likely that there was an error in sampling or analysis. If the TPB analysis is correct, then the rate of loss of TPB was $54 \mathrm{mg} / \mathrm{L} /$ day. If the Cs-137 and $\mathrm{K}^{+}$values are correct, then the TPB concentration must have been lower than measured and the rate of loss of TPB was greater than $54 \mathrm{mg} / \mathrm{L}$. Because of this uncertainty, the Table I entry for the decomposition rate in Experiment \#2 is listed as $>54 \mathrm{mg} / \mathrm{L} /$ day. In Experiment \#5, the available data yields an extremely high estimate of the rate of decomposition. Enough NaTPB 
WSRC-TR-96-0190

Page 8 of 35

September 6, 1996

was added to the slurry to produce an excess of $17,000 \mathrm{mg} / \mathrm{L}$. After mixing for 4 hours at ambient cell temperature $\left(27{ }^{\circ} \mathrm{C}\right)$, a diluted sample was taken. The sample contained very little NaTPB $(134 \mathrm{mg} / \mathrm{L})$ and indicates a decomposition rate of $100,000 \mathrm{mg} / \mathrm{L} /$ day. This rate is 2,000 times larger than observed in any of the other experiments reported here. Unfortunately, the sample was not analyzed until 37 days later. Thus, the excess NaTPB may have decomposed during this time period. The first sample after heating to $50{ }^{\circ} \mathrm{C}$ was taken at 16 days, but problems with the analysis resulted in no measurement of the $\mathrm{TPB}^{-}$concentration. However, the high soluble Cs-137 concentration indicates that little or no $\mathrm{TPB}^{-}$ was present at this time. The rate derived assuming not TPBremained after 16 days is $700 \mathrm{mg} / \mathrm{L} /$ day or about 15 times faster than measured in other experiments. The dilution of the sample during its preparation (see Appendix A for details) also contributes to the uncertainty about the Cs-137 concentrations. Because of these uncertainties, the Table I entry for the decomposition rate in Experiment \#5 is 1 isted as $>700 \mathrm{mg} / \mathrm{L} /$ day. Because of the problems and inconsistencies in the data from these two experiments, the results should be used with caution.

\section{Effect of Temperature}

The rate of the decomposition reaction increases significantly with temperature between 40 and $50{ }^{\circ} \mathrm{C}$. In general, the rate of decomposition is slow at $40{ }^{\circ} \mathrm{C}(0-5 \mathrm{mg} / \mathrm{L} /$ day $)$ and fast at $50{ }^{\circ} \mathrm{C}$ (34 to $63 \mathrm{mg} / \mathrm{L} /$ day). Experiments \#2 and \#5 suggest that the rate may be significantly faster. The temperature effect is clearly seen by comparing results from Experiment $4 \mathrm{~A}, 4 \mathrm{~B}, 4 \mathrm{C}$, and $4 \mathrm{D}$ (Figure 1). Based on this data, the energy of activation for the

FIGURE 1. Effect of Temperature on the TPB $^{-}$Decomposition Rate
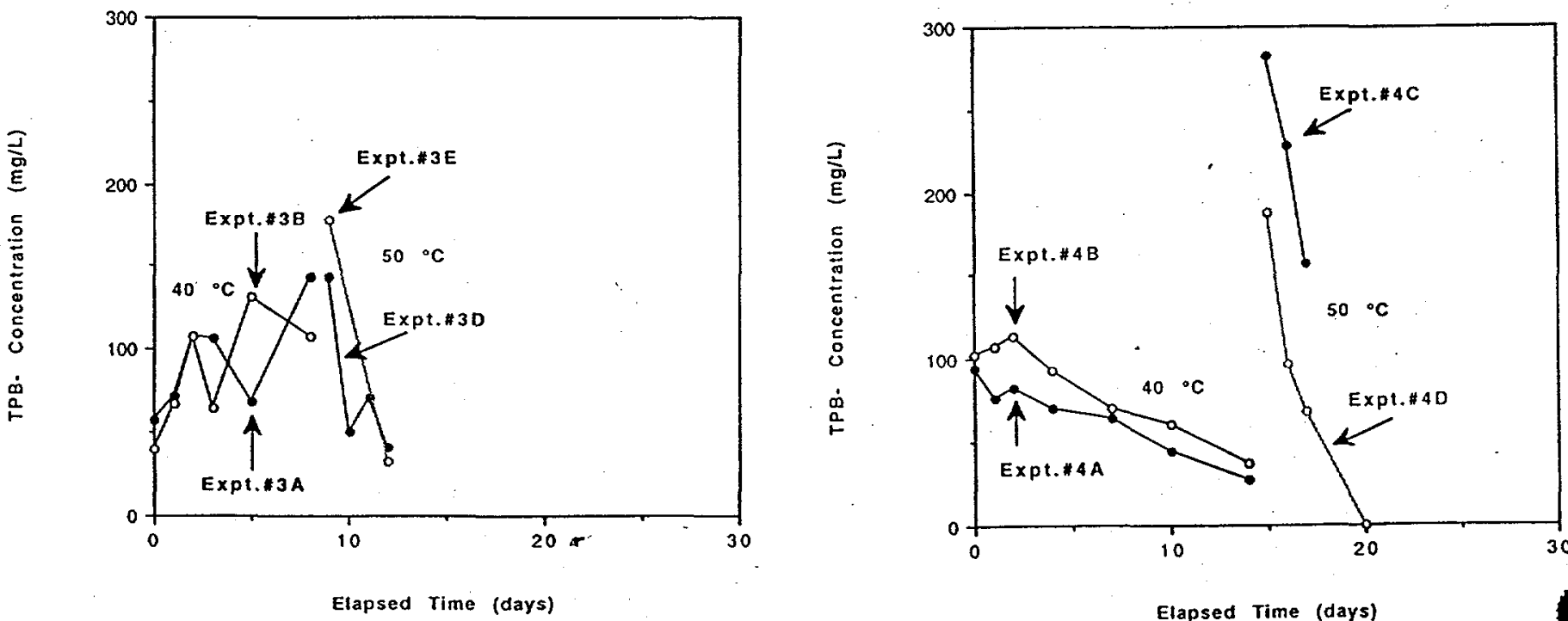
WSRC-TR-96-0190

Page 9 of 35

September 6, 1996

reaction is 160 to $215 \mathrm{~kJ} / \mathrm{mole}$. This is consistent with previous measurements on similar systems. ${ }^{1}$

The inconsistency of Experiment \#2 (higher rate at a lower temperature) may have been due to poor temperature control. The TPB decomposed largely during the first two days of the experiment when temperature readings were higher than the average. Over the entire experiment, the temperature readings averaged $39{ }^{\circ} \mathrm{C}$, but varied between 32 and $47{ }^{\circ} \mathrm{C}$. Some of this range was due to rapid changes of the air temperature in the oven from the on/off cycling of the heating element (see discussion in Appendix A). However, this cycling does not account for the entire range. The temperatures recorded during the first two days of the experiment were 45 and $47^{\circ} \mathrm{C}$, much higher than the average temperature. The actual temperature of the slurry was at least $42{ }^{\circ} \mathrm{C}$ and may have been several degrees higher. Thus, the high decomposition rate measured in this experiment may be partially due to the high oven temperature during the first two days.

\section{Effect of Weight Percentage Solids}

There appears to be a correlation between the rate of loss of TPB and the weight percentage of Tank $48 \mathrm{H}$ solids present in the slurry. The decomposition rates from Experiment \#4 (at 4 wt $\%$ solids) are consistently faster than corresponding results from Experiment 3 (at 0.6 wt $\%$ solids). Also, the two anomolous experiments (\#2 and \#5) both contained relatively high amounts of solids (Expt.\#2, 3.7 wt $\%$; Expt. \#5, 5.1 wt $\%$ ). This result implies that the solids either contain a catalyst (for example, heavy metals in the sludge portion of the solids), or provide a medium for the reaction (for example, the surface area of the KTPB particles).

The total solids listed in Table I includes both organic solids (KTPB and CSTPB), and inorganic solids (monosodium titanate and sludge). The inorganic solids were measured after dissolving the tetraphenylborate solids in acetonitrile. The inorganic solids were dissolved in aqua regia and analyzed to determine the elemental composition. The results are listed in Table III. The presence of boron suggests that some KTPB was probably left in the inorganic solids due to incomplete washing. The weight percentage of inorganic solids reported in Table I are corrected for the presence of KTPB assuming that the boron due to KTPB. The ratio of inorganic to total solids is relatively constant in all of the slurries $(0.13 \pm .03)$, as is the ratio of monosodium titanate to sludge, show by the ratio of $\mathrm{Ti} / \mathrm{Fe}(9 \pm 1)$. This is consistent with previous studies that found that monosodium titanate and sludge solids do not significantly separate from KTPB solids by gravity settling. ${ }^{5}$ Since these ratios were constant, the separate contribution of inorganic solids or organic solids to differences in the rate of decomposition of $\mathrm{TPB}^{-}$cannot be determined from this data set. 
WSRC-TR-96-0190

Page 10 of 35

September 6; 1996

TABLE III. Composition of Inorganic solids

Element

\begin{tabular}{|c|c|c|}
\hline Al & 3.1, & 1.9 \\
\hline B & .76 & 1.1 \\
\hline $\mathrm{Ba}$ & .08, & .05 \\
\hline $\mathrm{Ca}$ & .46 , & .25 \\
\hline $\mathrm{Cd}$ & .01 & .01 \\
\hline Co & .05, & .03 \\
\hline $\mathrm{Cr}$ & .31 , & .20 \\
\hline $\mathrm{Cu}$ & .06 & .04 \\
\hline $\mathrm{Fe}$ & 2.5 & 1.6 \\
\hline $\mathrm{Mg}$ & .56 & .36 \\
\hline Mn & .24 & .15 \\
\hline Mo & .01 & .01 \\
\hline $\mathrm{Na}$ & 6.6 & 4.5 \\
\hline $\mathrm{Ni}$ & .12 & .12 \\
\hline $\mathrm{P}$ & .16 & .08 \\
\hline $\mathrm{Pb}$ & .15 & .10 \\
\hline $\mathrm{Si}$ & 2.3 & 1.2 \\
\hline $\mathrm{Sn}$ & .03 & .02 \\
\hline Sr & .02 & \\
\hline $\mathrm{Ti}$ & 22.5 & 14.2 \\
\hline $\mathrm{V}$ & .03 & \\
\hline $\mathrm{Zn}$ & .07, & \\
\hline $\mathrm{Zr}$ & 03 & \\
\hline
\end{tabular}

Composition (wt \% in inorganic Expt\#2 Expt.\#3

3.1

.67

.08

.57

.04

$--$

.30

.06

2.9

.57

.25

$-$

4.8

.27

.20

1.

1.7

.02

23.3

$--$

.11 solids)

Expt.\#4

$2.8, \quad 1.4$

$1.3,1.5$

$.14, .05$

$.54, .25$

$.01, .00$

$.07, .03$

$.26, .15$

$.07, .03$

$1.7, .90$

$.40, .24$

$.17, .10$

$.03, .01$

$5.3, \quad 3.0$

$.15, .06$

$.24, .08$

$.29, \quad .11$

$1.7, \quad .87$

$.06, \quad .02$

$.02, .01$

$15.0,9.4$

$.05, .02$

$.11, \quad .04$

$.06 ; .02$

The elements found in the analysis of the sludge solids and their relative concentrations are similar to previously reported results. ${ }^{1}$

\section{Effect of Decomposition Products}

The concentrations of decomposition products (1PB and phenol) do not show a correlation with the rate of decomposition, although further study is warranted. In the experiments that showed rapid loss of $\mathrm{TPB}^{-}$(\#2, \#3D, \#3E, \#4C, \#4D, and \#5), the concentration of $1 \mathrm{~PB}$ varied between 111 and $1980 \mathrm{mg} / \mathrm{L}$ and the concentration of phenol varied between 1073 and $1579 \mathrm{mg} / \mathrm{L}$. These values encompass almost the entire range found for both compounds. The other major intermediates ( $3 \mathrm{~PB}$ and $2 \mathrm{~PB}$ ) were not measured because an analytical method was not available at SRTC. Their concentrations are expected to be linked to $1 \mathrm{~PB}$, which suggests that there is no correlation between them and the decomposition rate. This is supported by the similarity of the $\mathrm{TPB}^{-}$decomposition rate in Experiments \#4C (no intermediates added) and \#4D (with $3 \mathrm{~PB}$ and $2 \mathrm{~PB}$ added) . 
WSRC-TR-96-0190

Page 11. of 35

September 6, 1996

\section{Effect of NaTPB Source, Vessel Matexial, Tank 48H Sampling Date, and salt Concentration}

There does not appear to be any correlation between the reaction rate and the source of NaTPB, the materials of construction of the reaction vessels, the date the Tank $48 \mathrm{H}$ slurry was taken, or the concentration of the salt solution. At various times, these were proposed as possible causes for the high rate of decomposition in Experiment \#2. For example, high rates of decomposition have been observed with all. three sources of NaTPB (Tank 49H, AFF/Aquafine, Holley Oak), in reaction vessels from all three materials of construction (polyethylene, stainless steel, and carbon steel), in Tank 48H samples from $12 / 95$ and from 7/96, and from the entire range of sodium ion concentrations ( 3.5 to 5.1 molar).

\section{Effect of Batch Dilution}

Tests \#3B and \#6 were designed to examine the effect of the current Tank $48 \mathrm{H}$ slurry heel on the chemistry of a subsequent batch of waste. In both cases, decontamination was rapid and the NaTPB remained stable for an extended period of time. For example, in Test \#6, the majority of the excess NaTPB was still present after six weeks at $50^{\circ} \mathrm{C}$. The improved stability may be due to dilution of the active catalyst.

\section{Decomposition of Insoluble Tetraphenylborates}

During Experiment \#2, a sudden increase in the soluble cs-137 concentration was observed (Figure 2). Following the jump, the Cs-137 concentration continued to increase, but at a much slower rate. A corresponding increase in soluble $\mathrm{K}^{+}$ion was also observed. The jump to $550 \mathrm{nCi} / \mathrm{mL}$ of soluble cesium is equivalent to the decomposition of 0.10 wt $\%$ of the solids present, based on values of $4 \times 10^{5} \mathrm{Ci}$ and 200,000 gallons of slurry in Tank $48 \mathrm{H}$. If the change in potassium ion concentration is used to make the calculation (using 3.2 wt 8 KTPB in a slurry of density $1.14 \mathrm{~g} / \mathrm{mL}$ ), then a similar decomposition value of 0.17 wt 8 is obtained. The rate of increase in soluble Cs-137 following the jump is $12 \mathrm{nCi} / \mathrm{mL} /$ day. This value is about eight times larger than the current rate of increase in the Tank $48 \mathrm{H}$, but the difference may be due largely to the differences in temperature between the experiment and Tank $48 \mathrm{H}$ (less than $35^{\circ} \mathrm{C}$ since December 1995).

In Experiment \#5, the magnitude of the jump in soluble Cs-137 and its subsequant rate of increase are not clearly evident due to the large and apparently random scatter in the Cs-137 measurements. However, the extent of decomposition can be determined if the following are assumed or calculated:

(1) dilution during sampling did not dissolve any Cs-137.

(2) total decomposition of excess NaTPB yields $1170 \mathrm{mg} / \mathrm{L}$ boron in solution, and 
WSRC-TR-96-0190

Page 12 of 35

September 6, 1996

FIGURE 2. Increases in Soluble Cs-137 Following Decomposition of Tetraphenylborate

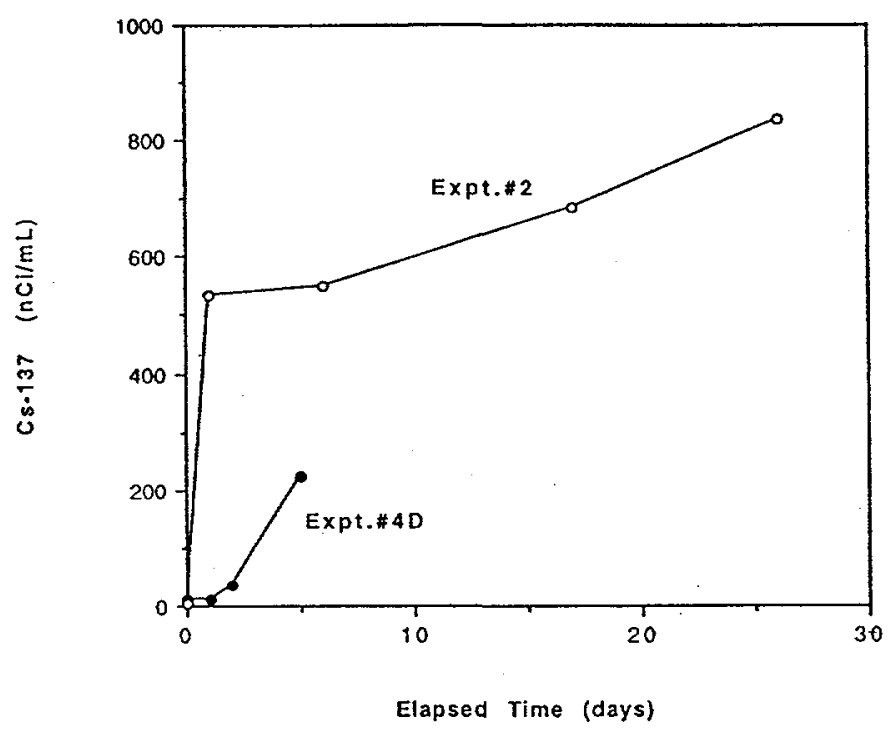

(3) the boron measurement (relative to $1170 \mathrm{mg} / \mathrm{L}$ ) is used to calculate the dilution of the sample.

On this basis, the extent of the solids decomposition in Expt.\#5 was $0.5 \%$ after 16 days when the first Cs-137 measurement was made.

In Experiment \#4D, a jump in Cs-137 was observed (Figure 2). However, since the slurry was entirely consumed in taking the sample showing the jump, there was no corroborating evidence that the jump was completed. (i.e, would not have been higher in a subsequent sample). In addition; the last sample was too small to obtain confirmation by $\mathrm{K}^{+}$analysis. However, assuming the jump was complete when the last sample was taken, then the change in the Cs137 concentration corresponds to a $0.04 \%$ decomposition of the solids.

In the other experiments, this phenomenon (jump in soluble Cs-137 followed by slow increase) was not observed, presumably because the excess $\mathrm{TPB}^{-}$was never completely consumed. It may have been observed if the experiments had continued until all the $\mathrm{TPB}^{-}$was decomposed.

\section{Decomposition Rates Expected in Tank $48 \mathrm{H}$ During PVT-1}

Eased on the preponderance of data from the experiments described above, the rate of loss of TPB ion in Tank $48 \mathrm{H}$ is expected to be $5 \mathrm{mg} / \mathrm{L} / \mathrm{hr}$ or less if the tank temperature is maintained below $40{ }^{\circ} \mathrm{C}$. This is based on the results of Experiments $4 \mathrm{~A}$ and $4 \mathrm{~B}$ which most closely imitate the planned addition of sodium tetraphenylborate in PVT-1. The rate of decomposition is proportional to the $\mathrm{TPB}^{-}$concentration," so a faster rate would be found if the initial 
WSRC-TR-96-0190

Page 13 of 35

September 6, 1996

$\mathrm{TPB}^{-}$concentration is higher ( $i . e$, if PVT-1 uses more than 200 gallons of NaTPB solution). The results from Experiments \#3A and \#3B support a decomposition rate of less than $5 \mathrm{mg} / \mathrm{L} /$ day. However, the results from Experiments \#2 and \#5 suggest that a factor not adequately controlled in these experiments could affect the rate and cause the excess NaTPB to decompose at a rate more than 10 times as fast.

Solids degradation and release of Cs-137 to solution is not likely to occur during PVT-1 as long as the rate of decomposition of the excess TPB $^{-}$is slow. Cs-137 release did not occur in Tank $48 \mathrm{H}$ following the decomposition during November and December 1995. However, even if it does occur, then the extent of the reaction, as indicated by the results of Experiments \#2, \#4D, and \#5, is only 0.05 to $0.5 \%$ of the solids in the tank. Since there are approximately $22,000 \mathrm{~kg}$ of tetraphenylborate solids in Tank $48 \mathrm{H}$, the decomposition would produce 10 to $100 \mathrm{~kg}$ of benzene.

\section{Effect of Nitrogen Inerting}

The reaction atmosphere has been shown to influence at least two aspects of the NaTPB decomposition reaction sequence. In air, the reaction exhibits an induction period ${ }^{1}$ and, when coupled with a high hydroxide salt solution medium, favors production of phenol rather than benzene. ${ }^{6}$ The presence of pure nitrogen results in no delay in the onset of the reaction and favors production of benzene relative to phenol. ${ }^{1}$ The length of the induction period observed in air depends upon reaction temperature. Induction periods as short as 100 hours have been observed in reactions at $70{ }^{\circ} \mathrm{C}$. An induction period of 450 hours was observed in a reaction at $40^{\circ} \mathrm{C}$. One aspect of the reaction that is not influenced by reaction atmosphere is the rate of TPB decomposition. If the induction period is ignored and reaction start time is set to coincide with the end of the induction period, the rate of decomposition in air is similar to (or even slightly faster than) the rate of decomposition in nitrogen.

After Experiment \#2, the ability to conduct tests under an inert atmosphere in the shielded cells became available. The were many reasons for selecting air rather than 5 vol o oxygen (in nitrogen) or pure nitrogen as the reaction atmosphere in the remaining experiments. First, the reaction conditions and products are more stable. With air, leakage through the septa on the reaction vessel (after frequent sampling) would not produce a significant change in the oxygen concentration in the vessel. If a 5 vol o oxygen (in nitrogen) or pure nitrogen atmosphere were used, air leakage would produce a significant change in the oxygen concentration within the reaction vessel. Second, use of air coupled with the high hydroxide concentration present in the test solution should produce phenol as the primary decomposition product rather than benzene. Benzene is volatile and difficult to accurately measure in reactions in the shielded cells. However, phenol is non-volatile and much more accurately measured in reactions conducted in the 
WSRC-TR-96-0190

Page 14 of 35

September 6, 1996

Shielded Cells. Third, all previous Shielded cells tests, including those that decomposed, were conducted using an air atmosphere. If the reaction atmosphere were not kept the same, comparisons between the new tests and the past tests would be difficult to perform. Fourth, no data was available on reaction behavior in 5 vol \% oxygen (in nitrogen). From this standpoint, expectations of the reaction behavior would be difficult to accurately predict and a reaction with this atmosphere would be more difficult to analyze. Lastly, ignoring the induction period, reaction in air is more conservative since the rate of decomposition in air is a little faster than the rate of decomposition in nitrogen.

\section{Possible Mechanisms for the Decomposition of Tetraphenylborate solids and suggestions for Further work}

Several mechanisms suggested for the decomposition of the insoluble tetraphenylborate solids are discussed below. Many of these have come from a review panel composed of Robert J. Hanrahan, R. Bruce King, E. J. Lahoda, George W. Parshall, and R. A. Smiley. Testing to investigate the factors affecting the solids decomposition will be included in the ITP chemistry technical plan.

The increase in soluble Cs-137 may be caused by an equilibrium shift due to formation of a cesium-organo compound. This does not seem likely since cesium ion in aqueous solution shows little tendency to form coordinate compounds. This can be easily explored by CsTPB solubility measurements in the presence of the organic decomposition compounds.

Possibly, $2 \mathrm{~PB}$ reacts with $\mathrm{KTPB} / \mathrm{CsTPB}$ solids via a dismutation reaction with the following stoichiometry:

$$
\left(\mathrm{C}_{6} \mathrm{H}_{5}\right)_{4} \mathrm{~B}^{-}+\left(\mathrm{C}_{6} \mathrm{H}_{5}\right)_{2} \mathrm{BOH} \longrightarrow 2\left(\mathrm{C}_{6} \mathrm{H}_{5}\right)_{3} \mathrm{~B}+\mathrm{OH}^{-}
$$

The reverse reaction has been published as the basis for the synthesis of tetraphenylborate. The product (two moles of 3PB) could decompose providing more $2 \mathrm{~PB}$ for the reaction with tetraphenylborate. This mechanism could be easily tested by additional experiments with intermediate compounds.

Inorganic solids may catalyze the decomposition of KTPB and CsTPB, as suggested by the faster rates at the higher solids

concentration. This reaction would very likely be mass transfer limited since solid-solid reactions are typically slow. This mechanism can be tested by measuring the effect of sludge solids on the reaction rate.

The increase in Cs-137 may be due to decomposition of selected solids, in particular, very fine particles with high surface to volume ratio. This could be studied by comparing the decomposition rates of freshly precipitated solids to those for aged or digested solids. 
WSRC-TR-96-0190

Page 15 of 35

September 6, 1996

The slowest rates of solids decomposition (i.e., the Tank 48H rate) may be due to catalyzed or thermal decomposition of soluble TPB (from dissolution of the KTPB), or it may be due to radiolytic degradation of the solids. Experiments using Co-60 gamma radiation can determine the contribution of the radiolytic mechanism.

\section{Conclusion}

Addition of as little as 0.0003 molar (100 mg/L) excess NaTPB to the slurry in Tank $48 \mathrm{H}$ is sufficient to reduce Cs-137 concentrations below $10 \mathrm{nCi} / \mathrm{g}$ within a few hours. This radioactivity level is well below the current and proposed limits in the ITP process requirements. Efficient decontamination was achieved using tetraphenylborate from either Tank $49 \mathrm{H}$, AFF/Aquafine, or Holley Oak Chemicals. There is no evidence that organic decomposition products in Tank $48 \mathrm{H}$ prevents acceptable decontamination as long as excess NaTPB is present. However, the excess NaTPB will be at risk of decomposing. The rate of the decomposition reaction increases significantly with temperature between 40 and $50{ }^{\circ} \mathrm{C}$. In general, the rate of decomposition is slow at $40{ }^{\circ} \mathrm{C}(0-5 \mathrm{mg} / \mathrm{L} /$ day $)$ and fast at $50{ }^{\circ} \mathrm{C}(34$ to 63 $\mathrm{mg} / \mathrm{L} /$ day). The majority of the small scale tests indicate that the excess NaTPB will degrade slowly if the tank temperature is kept below $40^{\circ} \mathrm{C}$. Two tests have shown faster decomposition rates, but the results of these tests are suspect. If the NaTPB decomposes rapidly, laboratory tests indicate that the concentration of soluble Cs-137. may increase to levels greater than they were prior to the precipitation. The extent of this decomposition is small, and has not exceeded $0.5 \%$ of the solids. 
WSRC-TR-96-0190

Page 16 of 35

September 6, 1996

\section{References}

1. D. D. Walker, M. J. Barnes, C. L. Crawford, R. F. Swingle, R. A. Peterson, M. S. Hay, and S. D. Fink, "Decomposition of Tetraphenylborate in Tank 48H (U)," WSRC-TR-0113, Rev.0, May 10, 1996.

2. O. Cardona-Quiles, "In-Tank Precipitation Plan for Process Verification Test," HLW-ITP-960247, Rev.0, draft.

3. D.A. Pervis, "Review of Revisions to ITP PR for WSRC-TR-960136 (U)," memorandum to A. W. Wiggins, et al, dated August 29, 1996. Westinghouse Savannah River Company, High Level Waste Management Division, "Process Requirements 241-82H Control Room (U),"WSRC-IM-91-63, Rev.13, June 1996, Section 3.1.3.2.

4. R. A. Peterson and R. S. Swingle, "Prediction of Tank 48H and Tank 50H Benzene Concentrations During Process Verification Testing Phase I (U)," WSRC-TR-96-0257, August 17, 1996.

5. L. L. Kilpatrick, "Composition of Washed and Unwashed In-Tank Precipitate (ITP) Solids (U)," WSRC-RP-96-7, Rev.0, JulY 16, 1996.

6. M. J. Barnes, unpublished results, see Laboratory Notebook \#WSRC-NB-95-184. 
WSRC-TR-96-0190

Page 17 of 35

September 6, 1996

\section{APPENDIX A Experimental Methods}

All experimental results are recorded in the following laboratory notebooks:

$$
\begin{aligned}
& \text { WSRC-NB-95-23 (D. D. Walker) } \\
& \text { WSRC-NB-96-613 (D. D. Walker) } \\
& \text { WSRC-NB-95-82 (C. A. Nash) }
\end{aligned}
$$

\section{Analyses}

Benzene analyses were performed by gas chromatography by personnel within Interim Waste Technology using Procedure IWT-OP005, Manual L12.1. The sample preparation method for radioactive samples in the shielded Cells has been described previously. ${ }^{1}$

The solids content of several slurries were measured in the Shielded Cells by the following procedure:
a. A portion of slurry $(5-10 \mathrm{~g})$ was weighed into a $30 \mathrm{~mL}$ sintered glass fritted filter ("Fine" porosity).
b. The salt solution was removed by filtration and the solids were washed with three $10 \mathrm{~mL}$ portions of water.
c. The washed solids were dried at $100{ }^{\circ} \mathrm{C}$ to constant weight.
d. The dry solids were washed with three $15 \mathrm{~mL}$ portions of: acetonitrile to dissolve the tetraphenylborate solids.
e. The inorganic residue was dried to constant weight at $100{ }^{\circ} \mathrm{C}$.

The inorganic residue was analyzed by treating the entire filter in aqua regia ( $30 \mathrm{~mL}$ ). The aqua regia was decanted to a $100-\mathrm{mL}$ volumetric flask. The filter was rinsed with water and the water added to the aqua regia, with final dilution to $100 \mathrm{~mL}$. All of the solids appeared to dissolve by this procedure. The results of these analyses are listed in Table III. Based on the boron results (and the ratio of boron to the other inorganic elements), it is apparent that the acetonitrile washes were not entirely adequate to remove all of the KTPB. The values for weight percentage of inorganic solids have been corrected for residual KTPB in the washed and dried inorganic residue assuming that all of the boron is due to KTPB.

All other chemical analyses were provided by the SRTC Analytical Development Section (ADS). Samples submitted for anlaysis were assigned computer tracking numbers (LIMS numbers) by ADS and the number is recorded in the laboratory notebook of the researcher that submitted the sample. All results were obtained by routine methods.

Tetraphenylborate is measured by two methods. At high concentrations ( $>0.01$ molar), the preferred method is 
WSRC-TR-96-0190

Page 18 of 35

September 6, 1996

potentiometric titration with silver ion. At lower concentrations it is measured by High Performance Liquid Chromatography (HPLC). Tetraphenylborate, phenylboronic acid, and phenol were measured by HPLC. Boron and transition metals were measured by ICP-ES atomic emission spectroscopy. Potassium was measured by atomic absorption spectroscopy. Cs-137 was measured by gamma ray spectroscopy using an intrinsic germanium high-resolution spectrometer. Common solution ions (nitrate, nitrite, sulfate, phosphate, fluoride, choloride, and oxalate) were measured by ion chromatography. Hydroxide, aluminate, and carbonate were measured by wet chemical techniques using acid/base titrations.

\section{Sources of NaTPB}

The following three sources of NaTPB were used in the experiments with Tank $48 \mathrm{H}$ slurry.

\section{Tank $49 \mathrm{H}$}

This solution was a composite of four VDS samples taken from Tank 49H in April 1996 (Sample numbers ITP-273, ITP-274, ITP-275, and ITP-276). For the decontamination and decomposition tests, the critical component in this solution was tetraphenylborate ion. The following results were obtained on two of the VDS samples in the composite:

Sample

PP-274

ITP -275

\begin{tabular}{llc} 
& \multicolumn{2}{c}{ Concentration } \\
TPB- & Phenol & PBA \\
(M) & (mg/L) & $(\mathrm{mg} / \mathrm{L})$
\end{tabular}

407

413
.024

.022

$$
\begin{aligned}
& <20 \\
& <20
\end{aligned}
$$

Biphenyl Terphenyl $(\mathrm{mg} / \mathrm{L}) \quad(\mathrm{mg} / \mathrm{L})$

6

5
2

2

Based on analyses of other recent samples, the composition of Tank $49 \mathrm{H}$ salt solution was:

$\begin{array}{ll}\text { Component } & \begin{array}{c}\text { Concentration } \\ \text { (molar) }\end{array} \\ \mathrm{Na}^{+} & 3.2 \\ \mathrm{NO}_{3}{ }^{-} & 0.62 \\ \mathrm{NO}_{2}^{-} & 0.90 \\ \mathrm{OH}^{-} & 0.17 \\ \mathrm{CO}_{3}{ }^{2-} & 0.28 \\ \mathrm{SO}_{4}^{2-} & 0.033 \\ \mathrm{AlO}_{2}{ }^{-} & 0.05 \\ \text { Oxalate } & 0.008\end{array}$

Reference: M. J. Barnes, "Inadvertent Transfer of Tank 49H Salt Solution: Status Report 1 (U), : WSRC-TR-96-0246, Rev.0 August 9, 1996. 
WSRC-TR-96-0190

Page 19, of 35

September 6, 1996

Table A-I. Composition of AFF and Holley oak NaTPB solutions

Component

NaTPB (molar)

$\mathrm{NaOH}$ (molar)

Phenol (mg/L)

$1 \mathrm{~PB}$ (mg/L)
Concentration

AFF Holley oak

0.58
0.10
1500
610

0.59

0.12

2100

480

\section{AFF NaTPB Solution}

This material was a composite of samples of the NaTPB solutions added to Tank $48 \mathrm{H}$ in september 1995. The concentrations of major components are listed in Table A-I and detailed analyses been described previously. ${ }^{1}$

\section{Holley oak}

This material was from a sample of NaTPB solution received from Holley Oak Chemicals. It was prepared from AFF NaTPB that was spray dried by Aquafine. This solution was prepared by Holley oak Chemicals with the intention of sending it to SRS for use in the ITP Process Verification Tests. The sample was identified as \#D-1558, pulled from the Holley Oak storage tank on $7 / 16 / 96$. The concentrations of major components are listed in Table A-I.

\section{Temperature Control During shielded Cells Tests}

Because of the high radioactivity in the Tank $48 \mathrm{H}$ slurries used in the following tests, the experiments were conducted in the SRTC Shielded Cells Facility. A drying oven was used to incubate the slurries at either 40 or $50^{\circ} \mathrm{C}$. Temperatures within the oven were measured using stainless steel-encased bimetal temperature sensing helix-type Ertco thermometers (Ever Ready Thermometer). Two thermometers were used, one with a stem length of 6 inches and one of 12 inches. The accuracy of the thermometers at two temperatures was checked prior to use against a mercury-in-glass thermometer traceable to NIST. Following use, the thermometers were checked in the Shielded cells using an ice/water bath and boiling water. Both before and after use the thermometers were found accurate to within $\pm 2{ }^{\circ} \mathrm{C}$.

During use, the oven air temperature was found to vary by $\pm 5{ }^{\circ} \mathrm{C}$ as the heating element cycled. The cycle time was approximately 30 minutes. However, when the thermometer was 
WSRC-TR-96-0.190

Page 20 of 35

September 6, 1996

TABLE A-II. Summary of Temperature Measurements

\begin{tabular}{|c|c|c|c|c|c|c|}
\hline Expt\# & $\begin{array}{c}\# \text { of } \\
\text { Measurements }\end{array}$ & High & \multicolumn{2}{|c|}{ tentectato } & \multicolumn{2}{|c|}{$\begin{array}{l}\text { Average } \\
\text { (range) }\end{array}$} \\
\hline 2 & 13 & 47 & 32 & 40 & 39 & $( \pm 8)$ \\
\hline $3 A \& B$ & 6 & 46 & 32 & 38 & 39 & $( \pm 8)$ \\
\hline $3 D \& E$ & 51 & 56 & 36 & 45 & 46 & $( \pm 10$ \\
\hline $4 A \& B$ & 67 & 45 & 37 & 40 & 40 & $( \pm 5)$ \\
\hline $4 C \& D$ & 21 & 54 & 48 & 52 & 52 & $( \pm 4)$ \\
\hline $5 \& 6$ & 51 & 52 & 45 & 50 & 50 & $( \pm 5)$ \\
\hline
\end{tabular}

Temperature $\left({ }^{\circ} \mathrm{C}\right)$

placed in water held in a polyethylene bottle or in one of the steel vessels used in the experiments, the temperature change during a cycle was less than $\pm 2{ }^{\circ} \mathrm{C}$.

It was also found that the oven temperature (the mid point in the cycle) did change during experiments, possibly due to inadvertent movement of the control dial. A summary of the temperature measurements is given in Table A-II. For experiments \#2, \#3, \#5, and \#6 the temperature was measured in air, and in Experiment \#4 the temperature of a bottle of water was measured. In the following descriptions of the experiments, the average and range are quoted.

\section{Experiment \#1: Cs-137 Decontamination Test}

The purpose of this experiment was to demonstrate that the Tank 48H slurry could be decontaminated to a level acceptable for processing and to determine the amount of Tank $49 \mathrm{H}$ solution required to achieve decontamination. For this experiment, a composite sample of Tank $48 \mathrm{H}$ slurry (94 mL) was prepared from the following three VDS samples taken on 5/7/96: ITP-289, ITP-290, and ITP-291. The decontamination test started on $5 / 22 / 96$.

The composite Tank $48 \mathrm{H}$ slurry was stirred in a small polyethylene bottle. Duplicate samples were taken for analysis before any Tank $49 \mathrm{H}$ solution was added. This initial slurry was divided in four parts and portions of Tank $49 \mathrm{H}$ salt solution were added to each part. The source of NaTPB was the composite solution from Tank $49 \mathrm{H}$ described above. The volume of Tank $49 \mathrm{H}$ solution was calculated as the equivalent number of gallons added to the 188,000 gallon inventory of slurry in Tank 48H. The experiment at 390 gal/tank corresponds to the stoichiometric amount of NaTPB required to precipitate the $\mathrm{K}^{+}$. The experiment at 140,000 gal/tank corresponds to transfer of the entire contents of Tank $49 \mathrm{H}$ to Tank $48 \mathrm{H}$. The slurries were stirred for 2 hours at ambient temperatures, then filtered through nitrocellulose disposable filter ( 0.45 micron nominal pore size). The filtrate was removed from the Shielded Cell and analyzed the the SRTC Analytical Development Section. The results are listed in 
WSRC-TR-96-0190

Page 21 of 35

September 6, 1996

TABLE A-III. Results for Experiment\# $1^{\dagger}$

TK 49H Vol. (gaI/tank)* 0

0

390

6000

12000

140000

\begin{tabular}{l} 
Cs -137 \\
$(\mathrm{nCi} / \mathrm{mI})$ \\
\hline $269 \pm 5$ \\
$284 \pm 6$ \\
$114 \pm 2$ \\
$1.9 \pm .05$ \\
$1.1 \pm .3$ \\
$0.4 \pm .02$
\end{tabular}

\begin{tabular}{lrrrr}
\multicolumn{3}{c}{ Final Concentrations } & \multicolumn{2}{c}{$(\mathrm{mg} / \mathrm{L})$} \\
$\underline{\mathrm{K}}-$ & $\underline{\mathrm{TPB}}-$ & $\underline{\mathrm{B}}$ & $\underline{\text { PBA }}$ & Pheno1 \\
4.1 & 64 & $488 \pm 5$ & 761 & 1147 \\
4.1 & 63 & $490 \pm 5$ & 728 & 1152 \\
3.5 & 68 & 484 & 658 & 1093 \\
0.34 & 66 & 504 & 668 & 1140 \\
0.30 & 134 & 480 & 650 & 1094 \\
0.20 & 1257 & 342 & 381 & 789
\end{tabular}

${ }^{\dagger}$ The experiment was completed on $5 / 22 / 96$ and the HPLC analyses on filtrate were completed by 5/24/96.

*The volume ratios used in the experiment are calculated as the equivalent number of gallons of Tank $49 \mathrm{H}$ solution that would have to be added to $188,000 \mathrm{gal}$ of slurry in Tank $48 \mathrm{H}$.

Table A-III. The analyses were completed within two days of filtering the solutions. Although a delay in analysis of the filtrate samples' will not affect measurements of Cs-137, $\mathrm{K}^{+}$, or $\mathrm{B}$, slow decomposition of TPB and the intermediate decomposition compounds (3PB, $2 \mathrm{~PB}$, and $1 \mathrm{~PB}$ ) could affect the amounts of $\mathrm{TPB}^{-}$, $1 \mathrm{~PB}$, and phenol observed.

\section{Experiment \#2: TPB Decomposition Test with Tk 49H NaTPB}

The purpose of this experiment was to determine the stability of the Tank 48H slurry after an NaTPB addition. The stability was monitored by measuring the rate of loss of $\mathrm{TPB}^{-}$and the rates of appearance of decomposition products. This experiment was the first that clearly showed rapid decomposition of the TPB ${ }^{-}$and a jump in soluble Cs-137.

For this experiment, the remainder $(23 \mathrm{~mL})$ of the Tank $48 \mathrm{H}$ slurry composite prepared for Experiment \#1 was combined with the following two samples taken from Tank $48 \mathrm{H}$ on 6/2/96: ITP-296 $(58 \mathrm{~mL})$ and ITP-297 (63 mL). To this was added $4.6 \mathrm{~mL}$ of Tank. $49 \mathrm{H}$ solution (ratio: $6,000 \mathrm{gal} \mathrm{Tk} 49 \mathrm{H} / 188,000 \mathrm{gal} \mathrm{Tk} 48 \mathrm{H}$ ). After stirring for 2 hours at ambient temperature, a $30 \mathrm{~mL}$ portion was filtered ( $0.45 \mathrm{micron}$ ) and the filtrate removed from the cell for a separate benzene generation test (see below). The remainder of the slurry $(107 \mathrm{~mL})$ was placed in a stainless steel reaction vessel (cylindrical, $4 \mathrm{~cm}$ diameter, $12 \mathrm{~cm}$ tall, $150 \mathrm{~mL}$ internal volume). A top plate containing three septa ports was bolted to the cylindrical vessel using a Teflon washer as a seal. The vessel was place in an oven at $39 \pm 8{ }^{\circ} \mathrm{C}$. Samples of slurry were removed from the vessel by inserting a stainless steel needle through silicone rubber septa in the ports on the lid. The samples (approximately $\mathrm{mL}$ ) were filtered and the filtrate analyzed for Cs-137 activity, potassium, TPB -1 PB, phenol, and total boron. Separate $1 \mathrm{~mL}$ portions were removed for benzene 
WSRC-TR-96-0190

Page 22 of 35

September 6, 1996

TABLE A-IV. Results for Experiment \#2,

TPB $^{-}$Decomposition Test with Tk49H NaTPB $\dagger$

Elapsed

Time

Cs-137

$\underline{B} \quad \underline{K} \pm$

Concentrations (mg/L)

(days) (nCi/mL)

$\begin{array}{rrrrrrrr}0 & 3 \pm .1 & 472 & 0.2 & 128 & 461 & 1271 & \\ 1 & 534 \pm 11 & 481 & 7.0 & 74 & 192 & 1417 & 29.5 \\ 6 & 551 \pm 11 & 461 & & <20 & 87 & 1738 & 39.8 \\ 17 & 685 \pm 11 & 492 & 10.1 & <20 & 70 & 1582 & \\ 24 & & & 6.3 & & & & \\ 26 & 836 \pm 11 & 497 & 11.2 & <20 & 28 & 2704 & \end{array}$

TTest started on 6/13/96. HPLC analyses were run after the following delays: Day 0, same day; Day 1, 11 days; Day 6, 5 days; Day 17, 2 days; Day 26, 2 days.

Figure A-1. Results from Experiment \#2

TPB $^{-}$Decomposition Test with Tk49H NaTPB
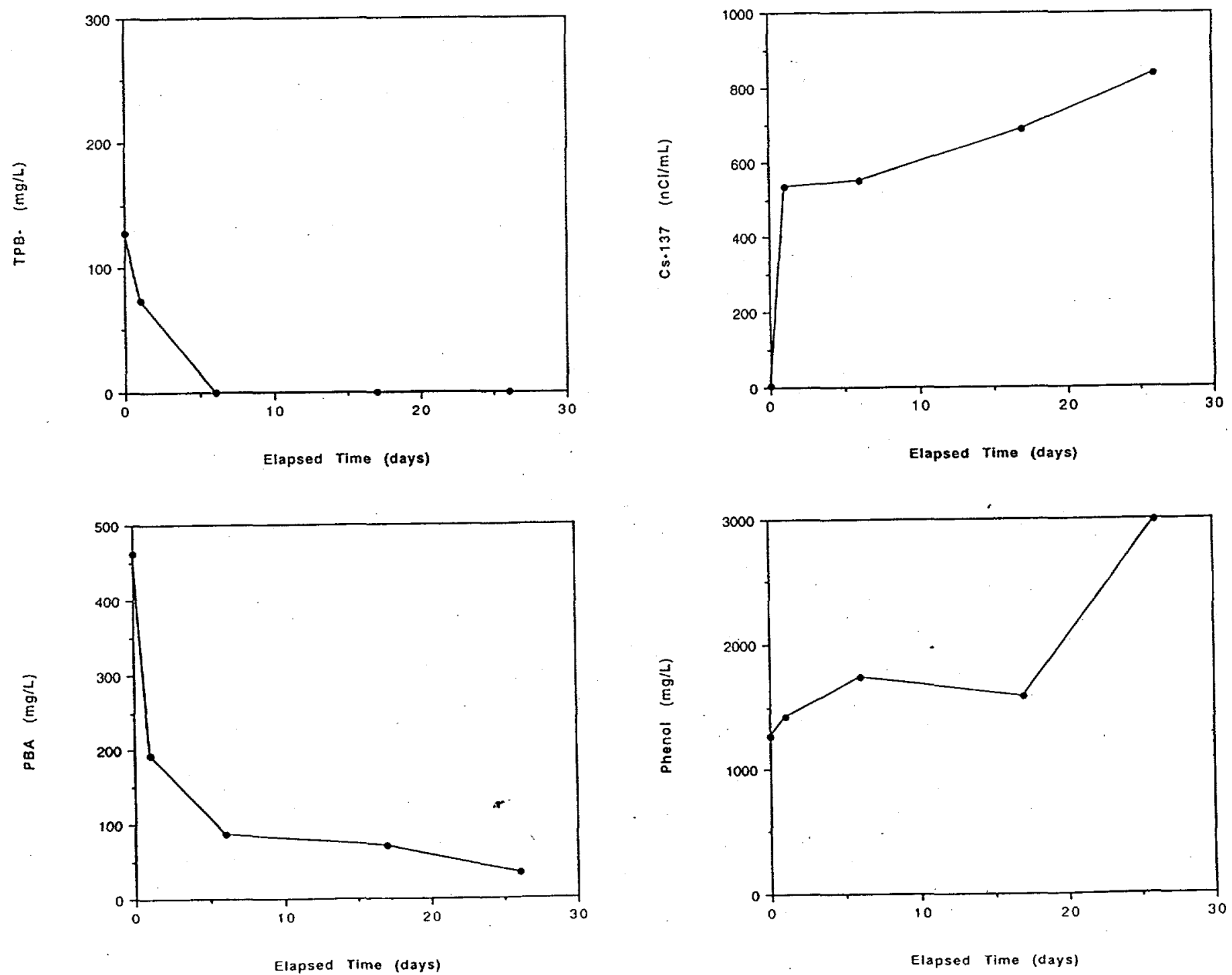
WSRC-TR-96-0190

Page 23 of 35

September 6, 1996

analyses. The results of these measurements are given in Table A-IV and graphs of the data are shown in Figure A-1. Many of the filtrate samples were stored for several days and in some cases, weeks, before analysis.

The $30 \mathrm{~mL}$ portion of filtrate removed at the start of the experiment was used in a separate test to measure the benzene generation rate in the filtrate. This sample was placed in a glass vessel at $50 \pm 3{ }^{\circ} \mathrm{C}$. It was continuously stirred and ventilated with air $(10 \mathrm{~mL} / \mathrm{min})$. The ventilation stream was sampled daily for benzene for 8 days. The benzene generation rate was $16 \pm 7 \mu \mathrm{g} / \mathrm{L} / \mathrm{hr}$.

At the end of Experiment \#2, the weight percentage solids of the remaining slurry was measured in duplicate and the results were:

$\begin{array}{ll}\text { Total insoluble solids: } & 3.5,3.9 \text { wt } \% \\ \text { Inorganic solids: } & 0.49,0.89 \text { wt } \% \\ \text { Inorganic solids (corrected): } 0.37,0.57 \text { wt } 8\end{array}$

The composition of the solids is listed in Table III.

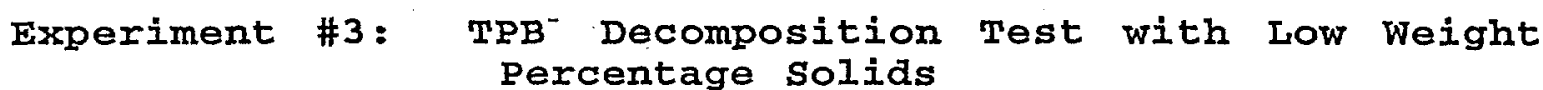

Experiment \#3A was a repeat of Experiment \#1 to determine if the previous observations were reproducible. The repeat experiment used a slurry sample that contained significantly fewer insoluble solids than Experiment \#1. There were several other minor differences between the two experiments. This experiment indicated that the excess NaTPB was much more stable than found in Experiment \#1.

Experiment \#3B, run simultaneously with \#3A, was a scoping experiment to determine if rapid decomposition and increase in soluble Cs-137 occurs in a new batch containing Tank 48H heel.

Experiment \#3C was a control experiment run simultaneously with \#3A and \#3B. The purpose was to determine if any changes occur in a slurry to which no new NaTPB was added.

Experiments \#3D and \#3E were continuations at higher temperature (both) and with organic intermediates added (\#3E) to determine the effect on the decomposition. Temperature is shown to be a major factor in faster decomposition rates.

For this experiment, a composite sample of Tank $48 \mathrm{H}$ slurry $(232 \mathrm{~mL})$ was prepared from the following three VDS samples taken on 6/28/96: ITP-311, ITP-312, and ITP-313. The experiment started on $7 / 7 / 96$.

The slurry was divided into three portions. Tank $49 \mathrm{H}$ solution.was added to one portion (Experiment \#3A). Simulated salt solution, 
WSRC-TR-96-0190

Page 24 of 35

September 6, 1996

dilution water, and AFF/Aquafine NaTPB solution (Batch \#AC-16) were added to the second portion (Experiment \#3B). The third portion was used as a control to which was added a small amount of dilution water (Experiment \#3C). A summary is shown in Table $A-V$.

As in Experiment \#2, the slurries were prepared and stirred for 2 hours at $24 \pm 5{ }^{\circ} \mathrm{C}$. After stirring, initial samples were taken and the remainder of the slurries placed in three metal containers similar to the ones used in Experiment \#2. The vessels for Expt.\#3A and \#3C were stainless steel, and the vessel for Expt. \#3B was carbon steel. The metal vessels were placed into an oven at $39 \pm 8{ }^{\circ} \mathrm{C}$. Periodically, the vessels were removed from the oven and $6 \mathrm{~mL}$ samples taken via syringe. The samples were filtered through a 0.45 micron filter, and the filtrate was analyzed for Cs-137, $\mathrm{TPB}^{-}$, phenol, and 1PB. The results of the analyses are 1isted in Table A-VI and graphs of the data are shown in Figure A-2. For these experiments, the HPLC analyses were made within 24 hours of filtering.

After eight days, this part of the experiment was terminated. The remaining slurry in two of the vessels was used in a continuation of the experiment at a higher temperature. Experiment \#3B was not continued. Experiment \#3A was continued at $50{ }^{\circ} \mathrm{C}$ without any other changes (Experiment \#3D). Experiment \#3C, the control, was adjusted by adding Tank $49 \mathrm{H}$ solution, and the three intermediate decomposition compounds (phenylboronic acid, diphenylborinic acid anhydride, and triphenylboron sodium hydroxide adduct). The expected concentrations in the new slurry were: $\mathrm{TPB}^{-}, 210 \mathrm{mg} / \mathrm{L} ; 3 \mathrm{~PB}, 220 \mathrm{mg} / \mathrm{L} ; 2 \mathrm{~PB}, 244 \mathrm{mg} / \mathrm{L}$; and $1 \mathrm{~PB}$, $1100 \mathrm{mg} / \mathrm{L}$. After stirring for 2 hours at $26 \pm 5{ }^{\circ} \mathrm{C}$ in a polyethylene bottle, the slurry was sampled and the remainder returned to the steel vessel and placed in the oven at $46 \pm 10{ }^{\circ} \mathrm{C}$ (Experiment \#3E). Both slurries (\#3D and \#3E) were sampled after 1,2 , and 3 days, at which time the experiment was terminated.

The samples were filtered through 0.45 micron filters before analysis. The results of the analyses are listed in Table A-VII.

At the end of this experiment, the following weight percentage solids measurements of the remaining slurry in Expt. \#3D were obtained:

$$
\begin{array}{ll}
\text { Total insoluble solids: } & 0.8 \text { wt } \% \\
\text { Inorganic solids: } & 0.11 \text { wt } \% \text {. } \\
\text { Inorganic solids (corrected) : } & 0.09 \text { wt } \frac{\%}{\circ}
\end{array}
$$

The composition of the solids is listed in Table III. 
WSRC-TR-96-0190

Page 25 of 35

September 6, 1996

TABLE A-V.Composition of Slurries Used in Experiment \#3

\begin{tabular}{|c|c|c|c|}
\hline \multirow[t]{2}{*}{ Experiment: } & $3 \mathrm{~A}$ & $3 B$ & \multirow{2}{*}{$\begin{array}{c}3 \mathrm{C} \\
\text { Control }\end{array}$} \\
\hline & peat \#2 & New Batch & \\
\hline Tk $48 \mathrm{H}$ composite (mL) & 83.1 & 23.3 & 82.7 \\
\hline Tk $49 \mathrm{H}$ solution $(\mathrm{mL})$ & 2.8 & 0 & 0 \\
\hline AFF/Aquafine NaTPB (mL) & 0 & 5.8 & 0 \\
\hline Water (mL) & 0 & 42.4 & 2.8 \\
\hline Simulate salt sol'n (mL) & 0 & 28.7 & 0 \\
\hline $\mathrm{Na}^{+}$(molar) & 3.4 & 4.7 & 3.4 \\
\hline
\end{tabular}

TABLE A-VI. Results for Experiments \#3A, 3B, and 3C

Elapsed

Time

(days)

0

1

2

3

5

8
Cs -137

$\frac{\text { Expt\# }}{3 A} \frac{(\mathrm{nCi} / \mathrm{mL})}{2.6}$

$3 \mathrm{~B}$

$3 \mathrm{C}$

$3 \mathrm{~A}$

$3 B$

$3 \mathrm{C}$

$3 \mathrm{~A}$

$3 \mathrm{~B}$

$3 \mathrm{C}$

$3 \mathrm{~A}$

$3 B$

$3 \mathrm{C}$

$3 \mathrm{~A}$

$3 B$

$3 \mathrm{C}$

$3 A$

$3 \mathrm{~B}$

$3 \mathrm{C}$
3.8

296

3.5

2.1

332

3.1

1.6

281

2.8

0.1

274

2.8

0.4

300

$3: 5$

0.3

318

Concentrations (mg/L)

TPB- PBA Phenol

$\begin{array}{rrr}57 & 152 & 1244 \\ 40 & 69 & 406 \\ <20 & 232 & 1405 \\ 72 & 219 & 1194 \\ 67 & 72 & 401 \\ <20 & 198 & 1251 \\ 107 & 252 & 1308 \\ 107 & 35 & 431 \\ <20 & 161 & 1184 \\ 106 & 154 & 1385 \\ 65 & 53 & 399 \\ <20 & 158 & 1310 \\ 68 & 110 & 1401 \\ 131 & 48 & 439 \\ <20 & 122 & 1250 \\ 144 & 122 & 1333 \\ 107 & 51 & 421 \\ 38 & 124 & 1352\end{array}$

TABLE A-VII. Results for Experiments \#3D, and 3E

Time Cs-137 Concentrations (mg/L)

(days) Expt\# (nCi/mL) $\underline{\text { TPB }}$ ) PBA phenol

$\begin{array}{rrr}0 & 3 \mathrm{E} & 5.5 \\ 1 & 3 \mathrm{D} & 7.4 \\ & 3 \mathrm{E} & 9.1 \\ 2 & 3 \mathrm{D} & 4.6 \\ & 3 \mathrm{E} & 21.8 \\ 3 & 3 \mathrm{D} & 11.8 \\ & 3 \mathrm{E} & 8.1\end{array}$

$178 \quad 922 \quad 1442$

$50 \quad 108 \quad 1316$

$-{ }^{*} \quad 809 \quad 1521$

$\begin{array}{lll}71 & 68 & 1498\end{array}$

$--* \quad 797 \quad 1756$

$41: \quad<20 \quad 1541$

$32 \quad 214 \quad 2057$

*Because of the high concentrations of decomposition products, the TPB peak in the HPLC analysis was not adequately resolved. 
WSRC-TR-96-0190

Page 26 of 35

September 6, 1996

Figure A-2. Results from Experiment \#3

TPB $^{-}$Decomposition Test with Low Weight

Percentage Solids
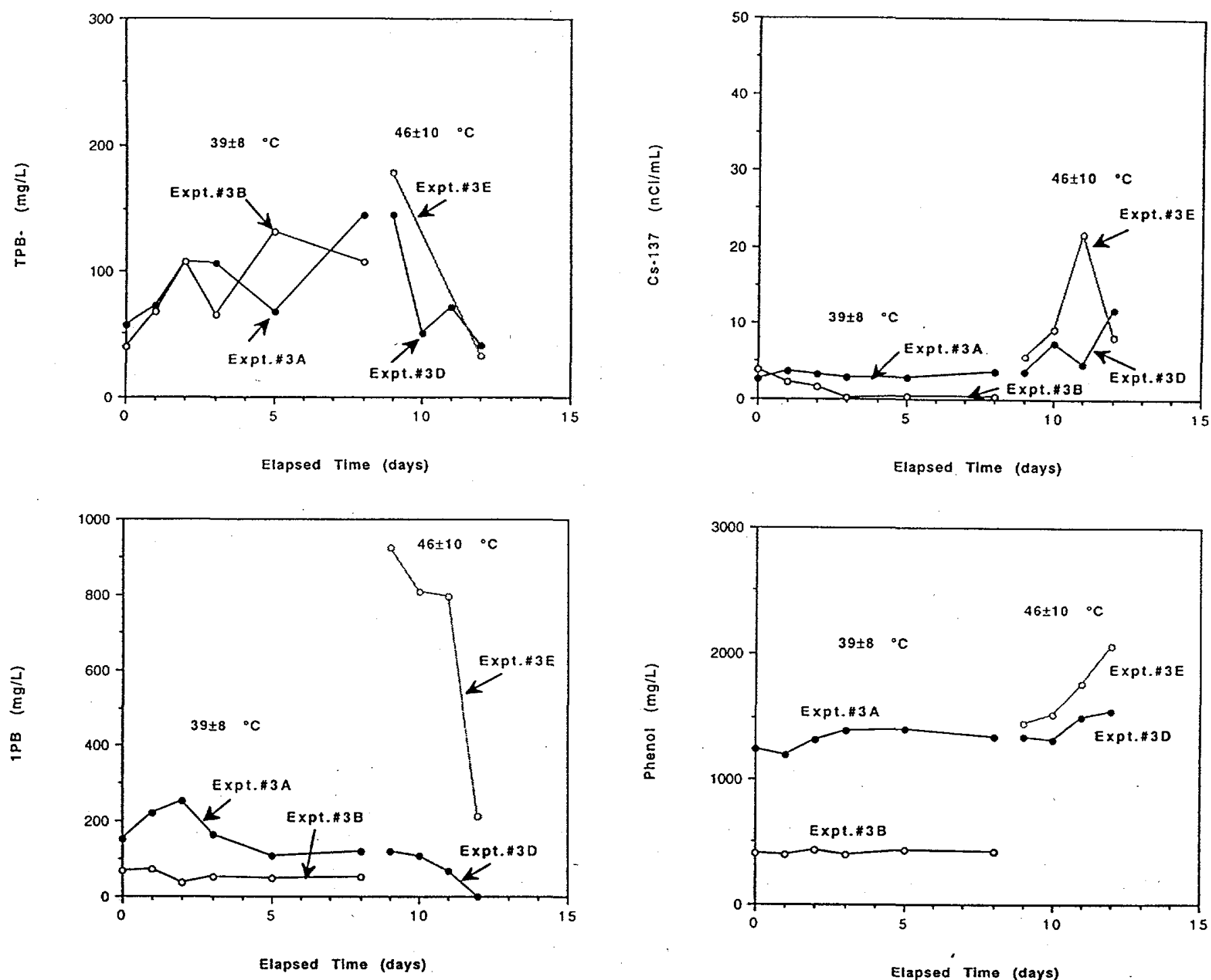

Experiment \#4: TPB $^{-}$Decomposition Test at High Weight Percentage Solids

Experiment \#4 measured the effect of insoluble solids on the decomposition rate. It was run in duplicate (\#4A and \#4B) to determine the reproducibility of the procedure. The imsoluble solids content was similar to Experiment \#2 and higher than Experiment \#3. 
WSRC-TR-96-0190

Page 27 of 35

September 6, 1996

Experiments \#3D and \#3E were continuations at higher temperature (both) and with organic intermediates added (\#3E) to determine the effect on the decomposition.

For this experiment, a composite sample of Tank $48 \mathrm{H}$ slurry $(194 \mathrm{~mL})$ was prepared from the following VDS samples.

$\begin{array}{ll}\text { ITP-320 } & (7 / 13 / 96) \\ \text { ITP-321 } & (7 / 13 / 96) \\ \text { ITP-322 } & (7 / 13 / 96) \\ \text { ITP-323 } & (7 / 14 / 96) \\ \text { ITP-324 } & (7 / 14 / 96) \\ \text { ITP-325 } & (7 / 14 / 96)\end{array}$

$\operatorname{ITP}-328(7 / 17 / 96)$

ITP-329 $(7 / 17 / 96)$

$\operatorname{ITP}-330(7 / 17 / 96)$

$\operatorname{ITP}-331(7 / 17 / 96)$

The total insoluble solids in these samples was low relative to the slurry used in Experiment \#2, so the solids were concentrated by decanting clear supernate from the top of the settled slurry. The original volume of approximately $675 \mathrm{~mL}$ was reduced to $194 \mathrm{~mL}$. The experiment using this composite slurry started on $7 / 22 / 96$.

A portion of the original slurry was used to measure the weight percentage solids:

$$
\begin{array}{ll}
\text { Total insoluble solids: } & 4.0,4.1 \text { wt } \% \\
\text { Inorganic solids: } & 0.66,1.34 \text { wt } \% \\
\text { Inorganic solids (corrected): } 0.38,0.67 \text { wt \% }
\end{array}
$$

The composition of the solids is listed in Table III.

The slurry was divided into two portions (89 $\mathrm{mL}$ ). Holley Oak Chemicals NaTPB solution $(0.12 \mathrm{~mL})$ was added to each portion (Experiment \#4A and 4B). As in previous experiments, the slurries were prepared and stirred for 2 hours at $27 \pm 5{ }^{\circ} \mathrm{C}$ in polyethylene bottles. After stirring, initial samples were taken and the remainder of the slurries were placed in two new carbon steel containers similar to the ones used in previous experiments. Before use, the vessels had been rinsed'with acetone, then water, then soaked for 22 hours in $0.5 \mathrm{M} \mathrm{NaOH}$, then rinsed thoroughly with water again. After adding the slurries, the metal vessels were placed into an oven at $40 \pm 5{ }^{\circ} \mathrm{C}$.

Periodically; the vessels were removed from the oven and $6 \mathrm{~mL}$ samples taken via syringe. The samples were filtered through a 0.45 micron filter, and the filtrate analyzed for Cs-137, TPB phenol, and 1PB. The results of the analyses are listed in Table A-VIII and graphs of the data are shown in Figure A-3. For these experiments, the HPLC analyses were made within 24 hours of. filtering.

After fourteen days, this part of the experiment was terminated. The remaining slurry in the two of vessels was used in a continuation of the experiment at $50 \pm 5^{\circ} \mathrm{C}$. Experiment \#4A 
WSRC-TR-96-0190

Page 28 of 35

September 6, 1996

TABIE A-VIII. Results for Experiments \#4A and $4 \mathrm{~B}$

\section{Elapsed}

Time

(days)
Expt\#

Expt\#
Cs -137

$(\mathrm{nCi} / \mathrm{mL})$

$\begin{array}{rrrrrr}0 & 4 \mathrm{~A} & 11.7 & 94 & 93 & 1164 \\ 1 & 4 \mathrm{~B} & 5.0 & 103 & 102 & 1181 \\ & 4 \mathrm{~A} & 9.7 & 77 & 97 & 1150 \\ 2 & 4 \mathrm{~B} & 9.2 & 107 & 115 & 1139 \\ & 4 \mathrm{~A} & 13.0 & 83 & 111 & 1131 \\ 4 & 4 \mathrm{~B} & 17.5 & 113 & 108 & 1119 \\ & 4 \mathrm{~A} & 23.3 & 71 & 98 & 1088 \\ 7 & 4 \mathrm{~B} & 16.2 & 93 & 106 & 1143 \\ & 4 \mathrm{~A} & 17.4 & 65 & 94 & 1150 \\ 10 & 4 \mathrm{~B} & 12.7 & 71 & 102 & 1153 \\ & 4 \mathrm{~A} & 20.0 & 44 & 88 & 1154 \\ 14 & 4 \mathrm{~B} & 20.4 & 61 & 93 & 1141 \\ & 4 \mathrm{~A} & 32.1 & 27 & 80 & 1138 \\ & 4 \mathrm{~B} & 24.2 & 37 & 66 & 1244\end{array}$

TABLE A-IX. Results for Experiments \#4C and 4D

Elapsed

Time

(days) Expt\#

$\begin{array}{ll}0 & 4 C \\ & 4 D \\ 1 & 4 C \\ & 4 D \\ 2 & 4 C \\ & 4 D \\ 5 & 4 D\end{array}$

Cs -137

(nCi/mL)

1.4
10.2
2.8
11.8
4.7
37
222

Concentrations (mg/L) TPB- PBA Phenol 
WSRC-TR-96-0190

Page 29 of 35 .

September 6, 1996

Figure A-3. Results from Experiment \#4, TPB-

Decomposition Test with High Weight

Percentage Solids
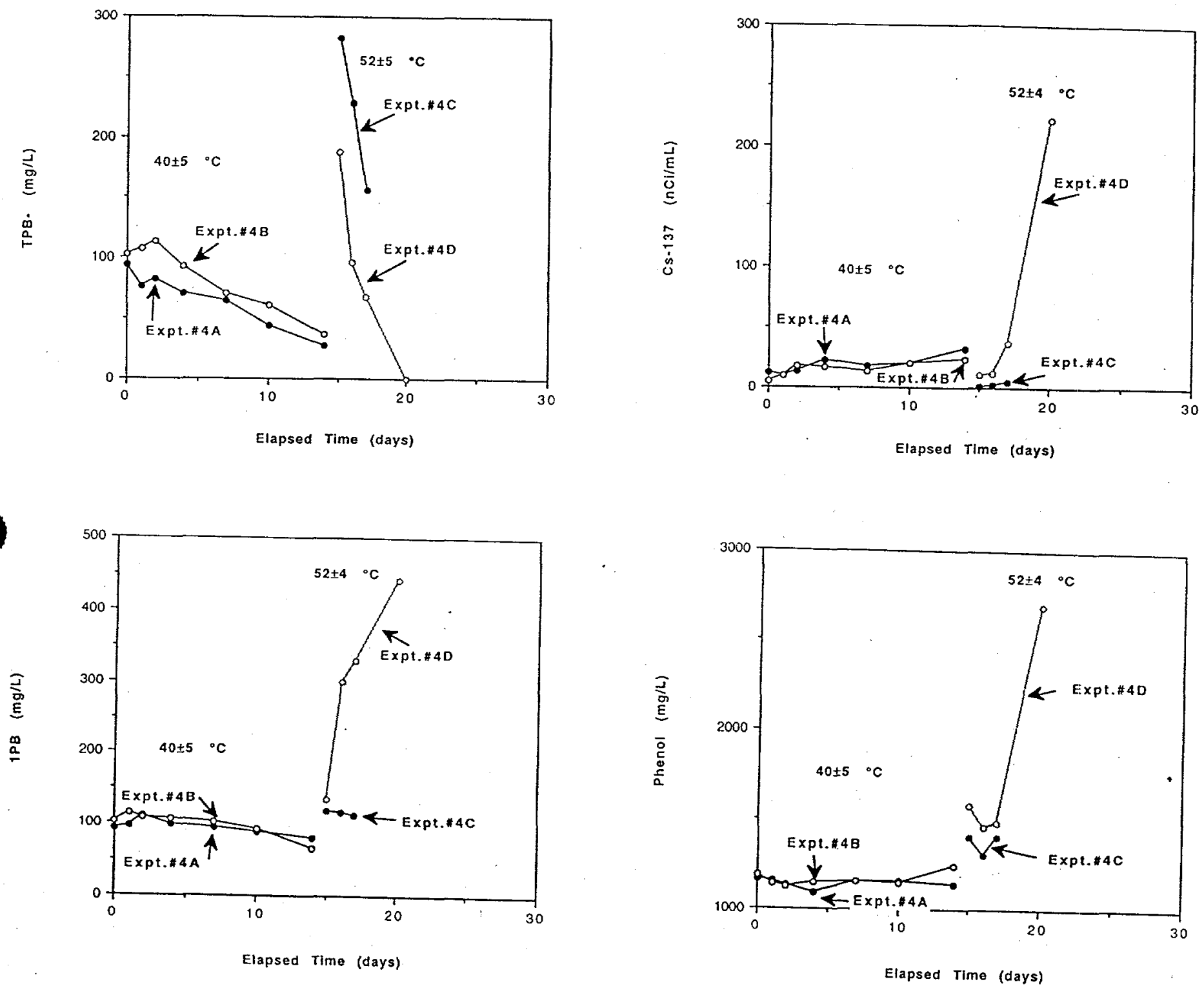

$F$ 
WSRC-TR-96-0190

Page 30 of 35

September 6, 1996

Experiment \#5: TPB $^{-}$Decomposition Test with AFF/Aq NaTPB

The purpose of this experiment was to determine if NaTPB added to the Tank 48H slurry would decompose. This was the first attempt to observe the decomposition reaction in a highly radioactive slurry. The protocol for the test, particularly the sampling frequency, the method of sample preparation (dilution followed by filtration), and the analytical methods used to follow the reaction (HPLC but not Cs-137), were selected based on an expectation of a slow response in the system. Consequently, the results that were obtained were too sparse to adequately determine when or how fast the reaction occurred.

For this experiment, a composite of the following two Tank $48 \mathrm{H}$ VDS slurry samples was made:

$$
\begin{array}{ll}
\text { ITP-216 } & (12 / 18 / 95) \\
\text { ITP-217 } & (12 / 18 / 95)
\end{array}
$$

The experiment started on $3 / 18 / 96$.

A $10.0 \mathrm{~mL}$ sample of AFF/Aquafine NaTPB solution was dried at $40 .{ }^{\circ} \mathrm{C}$ yielding 1.8 grams of solids. These solids were placed in a 125-mL polyethylene bottle and $104 \mathrm{~mL}$ of the Tank $48 \mathrm{H}$ composite added. The slurry was stirred at $27 \pm 5{ }^{\circ} \mathrm{C}$ for four hours and then an initial sample taken. The slurry was stored unstirred in an oven at $50 \pm 5{ }^{\circ} \mathrm{C}$. Periodically, the bottle was removed from the oven and a $5 \mathrm{~mL}$ sample taken for analysis.

The samples $(5 \mathrm{~g})$ were weighed into a glass beaker and $5 \mathrm{~mL}$ of dilution water added to dilute the sodium ion concentration and dissolve the excess sodium tetraphenylborate. After stirring for 15 minutes, the slurry was filtered. The beaker was washed with an additional $5 \mathrm{~mL}$ of water and the washwater passed through the filter containing the slurry solids. The combined filtrate was removed from the Shielded Cells for analysis. The results of these analyses are listed in Table A-X. The HPLC analyses from this experiment were delayed several days or even weeks following filtration. Because of the washing of the solids and. consequent dilution of the filtrate sample, gamma scans for soluble Cs-137 were not measured during this experiment. However, at the end of the experiment, an undiluted sample was taken and the diluted samples from earlier in the experiment were submitted for gamma counting. The insoluble solids collected in the filter were dried to constant weight. The results are also listed in Table A-X.

At the end of the experiment, it was found that the amount of rinse water used to clean the beaker and wash the solids was not measured accurately after the first sample... Rinse water amounts larger than $5 \mathrm{~mL}$ were used, but the exact amounts were not measured or recorded. Therefore, the concentrations 1isted in Table A-X cannot be used to determine absolute amounts of the components. 
WSRC-TR-96-0190

Page 31 of 35

September 6, 1996

TABLE $A-X$. Results for Experiment\#5, TPB ${ }^{-}$Decomposition Test with AFF/Aq NaTPB

\begin{tabular}{|c|c|c|c|c|c|c|}
\hline $\begin{array}{l}\text { Elapsed } \\
\text { Time }\end{array}$ & $\begin{array}{l}\text { Insoluble } \\
\text { Solids }\end{array}$ & \multicolumn{3}{|c|}{ Concentration } & $(/ L) *$ & $\mathrm{Cs}-137$ * \\
\hline (days) & (wt \%) & Boron & NaTPB & $1 \mathrm{~PB}$ & Pheno1 & $(\mathrm{nCi} / \mathrm{mL})$ \\
\hline 0 & -- & 635 & 138 & 1980 & 1073 & -- \\
\hline 16 & -- & 292 & -- & 1139 & 819 & 637 \\
\hline 24 & 5.2 & 291 & -- & 1015 & 1030 & 1319 \\
\hline 29 & 4.5 & 257 & 24 & 765 & 1079 & 908 \\
\hline 36 & 4.1 & 279 & 22 & 575 & 1297 & 1077 \\
\hline 44 & 4.7 & 284 & 15 & 372 & 1485 & 1459 \\
\hline 51 & 5.4 & 338 & 38 & 148 & 1797 & 501 \\
\hline 58 & 6.7 & 463 & 28 & 74 & 2543 & 1710 \\
\hline 65 & 4.8 & 200 & 36 & 20 & 1714 & 793 \\
\hline 72 & -- & 367 & 26 & 22 & 1989 & 1887 \\
\hline 107 & & & & & & $3800 * *$ \\
\hline
\end{tabular}

*These are concentrations of components in the diluted filtrate. The intended dilution factor was approximately $\times 3$, but higher dilutions were regularly used after the first sample.

**No dilution.

\section{Experiment \#6: New Batch Simulation Test}

The purpose of this test was to determine the amount of sodium titanate required for the proposed ITP Batch \#2 composition and to determine the stability of NaTPB in a second ITP batch precipitated in the presence of a heel of Tank $48 \mathrm{H}$ slurry.

This experiment was initiated by D. T. Hobbs in the March 1996 to determine the sodium titanate requirement (see D. T. Hobbs and D. D. Walker, "Preliminary Results from Radioactive ITP Batch \#2 Test," (U), SRT-LWP-96-0042, April 9, 1996, reproduced in Appendix B). The following slurry $(100 \mathrm{~mL})$ was prepared in a 120 mL polyethylene bottle:

$\begin{array}{lr}\text { Tank 48H slurry (ITP-236, 1/21/96) } & 22.3 \mathrm{~g} \\ \text { Tank 49H solution }(2 / 96) & 19.9 \mathrm{~g} \\ \text { Tank 25F solution }(12 / 1 / 95) & 23.1 \mathrm{~g} \\ \text { Tank 26F solution }(11 / 8 / 95) & 35.5 \mathrm{~g} \\ \text { NaTPB solution (AFF/Aquafine, } 0.554 \mathrm{M}) 6.8 \mathrm{~mL}\end{array}$

The final slurry was estimated to contain 1 wt $\%$ insoluble solids at $5.0 \mathrm{M}$ sodium ion.

After stirring for one week in the shielded Cells at ambient temperatures, the soluble cesium-137 concentration was still $300 \mathrm{nCi} / \mathrm{g}$. On $3 / 14 / 96$, "an additional $5.3 \mathrm{~mL}$ of the $0.554 \mathrm{NaTPB}$ solution was added and the slurry stirred overnight. By calculation, this addition of NaTPB produced an NaTPB excess of 
WSRC-TR-96-0190

Page 32 of 35

September 6, 1996

TABLE A-XI. Results for Experiment\#6, New Batch Simulation Test

$\begin{array}{lccccc}\begin{array}{l}\text { Elapsed } \\ \text { Time } \\ \text { (days) }\end{array} & \begin{array}{c}\text { Insoluble } \\ \text { Solids } \\ \text { (wt } \%)\end{array} & \begin{array}{c}\text { Concentration } \\ \text { NaTPB }\end{array} & \begin{array}{c}\text { 1PB } \\ \text { (mg/L)* } \\ \text { Phenol }\end{array} & \begin{array}{c}\text { Cs-137 } \\ \text { (nCi/mL) }\end{array} \\ 1 & 2.3 & 3010 & 86 & 210 & \\ 24 & & 1900 & 153 & 362 & 4.8 * * \\ 27 & 2.8 & 1622 & 36 & 393 & \\ 32 & 3.6 & 1958 & 14 & 393 & \\ 39 & 3.0 & 1300 & 5 & 339 & \\ 47 & 3.4 & 1605 & 17 & 513 & \\ 54 & 4.0 & 1694 & 18 & 574 & \\ 61 & 2.5 & 1501 & <20 & 551 & \\ 68 & 1.9 & 1143 & <20 & 501 & \\ 75(5 / 29 / 96) & & 1387 & <20 & 693 & \\ 110(7 / 3 / 96) & & & & & \end{array}$

*These are concentrations of components in the diluted filtrate. The intended dilution factor was approximately $x 3$, but higher dilutions were regularly used after the first sample.

**No dilution.

$10,000 \mathrm{mg} / \mathrm{L}$. At this time the weight percentage of solids was measured and found to be 2.3 wt $\%$. On $3 / 18 / 96$, the slurry was placed in an oven at $50 \pm 5{ }^{\circ} \mathrm{C}$. Periodically it was removed and samples taken for analysis. The samples $(5 \mathrm{~g})$ were weighed into a glass beaker and $5 \mathrm{~mL}$ of dilution water was added to dilute the sodium ion concentration and dissolve the excess sodium

tetraphenylborate. After stirring for 15 minutes, the slurry was filtered. The beaker was washed with an additional $5 \mathrm{~mL}$ of water and the washwater passed through the filter containing the slurry solids. The combined filtrate was removed from the Shielded Cells for analysis. The insoluble solids collected in the filter were dried to constant weight. The results of these analyses are listed in Table A-XI. Because of the washing of the solids and consequent dilution of the filtrate sample, gamma scans for. soluble Cs-137 were not measured during this experiment. However, after 24 and 110 days, a portion of filtrate was removed and the soluble Cs-137 concentration measured.

At the end of the experiment, it was found that the amount of rinse water used to clean the beaker and wash the solids was not measured accurately after the first sample. Rinse water amounts larger than $5 \mathrm{~mL}$ were used, but the exact amounts were not mesured or recorded. Therefore, the concentrations listed in Table A-XI cannot be uséd to determine absolute amounts of the components. 
WSRC-TR-96-0190

Page 33 of 35

September 6, 1996

\section{APPENDIX B \\ Memorandum Describing Preliminary Results from \\ Experiment\# 6}

SAVANNAH RIVER TECHNOLOGY CENTER

INTEROFFICE MEMORANDUM

SRT-LWP-96-0042

April 9, 1996

To:

S. D. Fink, 773-A

From: $\quad$ D. T. Hobbs, 773-A and D. D. Walker, 773-A

\section{Preliminary Results from Radioactive ITP Batch \#2 Test}

Summary

Recently a bench-scale test was conducted in the Shielded Cells of SRTC to determine if sufficient monosodium titanate (MST) exists in Tank $48 \mathrm{H}$ to remove actinides in the second ITP batch and meet the Saltstone feed limit of $18 \mathrm{nCi} / \mathrm{g}[1]$. The results indicate that no additional MST is required in ITP Batch $\$ 2$ per the batch plan using waste from Tanks $49 \mathrm{H}, 25 \mathrm{~F}$ and $26 \mathrm{~F}[2]$. A second addition of sodium tetraphenylborate (NaTPB) was required to reduce the Cs-137 activity in the liquid phase to helow the Filtrate Hold Tank and Saltstone feed limits of $100 \mathrm{nCi} / \mathrm{g}[1]$. A complete report will be issued upon completion of the testing for organic decomposition.

\section{Experimental}

The following quantities of tank samples were placed in a polyethylene bottle equipped with a magnetic stirring bar: 22.494 grams $(19.1 \mathrm{~mL}$ ) Tank 48H slurry (ITP-236/TTP235), 20.016 grams (17.8 mL) Tank 49H (ITP-247), 23.041 grams (16.5 mL) Tank 25F (sample dated 12/1/95) and 14.502 grams (11.2 mL) Tank 26F (sample dated 11/8/95). To this mixture, 35.5 grams $(35.5 \mathrm{~mL})$ of inhibited water $(0.012 \mathrm{M} \mathrm{NaOH})$ was added and the mixture vigorously stirred for 30 minutes. To the diluted mixture, $6.81 \mathrm{~mL}$ of a NaTPB solution $(0.554 \mathrm{M})$ was added dropwise over a 3 minute period. The resulting slurry was vigorously stirred at ambient cell temperature (ca. $25^{\circ} \mathrm{C}$ ). After 161 hours $(6.7$ days), 10 $\mathrm{mL}$ of slurry was filtered through a $0.45 \mu \mathrm{m}$ pore size disposable Nalgene ${ }^{\otimes}$ filter. The filtrate was removed from the Shielded Cells and aralyzed for total alpha activity and Cs137 activity. After standing for 8 days, an additional $5.27 \mathrm{~mL}$ of the NaTPB solution was added and the slurry vigorously stirred overnight. The slurry was allowed to stand at ambient cell temperature for 3 days and then placed in an oven heated to $70^{\circ} \mathrm{C}$. After 21 days, $10 \mathrm{~mL}$ of slurry was removed and filtered through a $0.45 \mu \mathrm{m}$ pore size disposable Nalgene $^{\star}$ filter. The filtrate was removed from the Shielded Cells and analyzed for Cs-137 activity.

Results and Discussion

The measured total alpha and Cs-137 activities for the two filtrate samples are provided in Table I. The total alpha activity after the first NaTPB addition was deiermined to be 0.48 $\mathrm{nCi} / \mathrm{g}$, which is well below the Saltstone feed iimit of $13 \mathrm{nCi} / \mathrm{g}$. Thus, it is concluded that no additional MST will be required in the second ITP batch to meet the Saltstone Feed limit for total alpha activity.

The test indicated that a calculated $38 \%$ mole excess of NaTPB was not sufficient to remove Cs-137 activity and meet the corresponding Filtrate Hold Tanks and Saltstone Feed limits of $100 \mathrm{nCi} / \mathrm{g}$. However, after a second addition of $\mathrm{NaTPB}$ to bring the calculated 
WSRC-TR-96-0190

Page 34 of 35

September 6, 1996

mole excess of NaTPB to $144 \%$, the Cs-137 activity was $4.0 \mathrm{nCi} / \mathrm{g}$, which is well below the $100 \mathrm{nCi} / \mathrm{g}$ limit. Possible explanations for the low cesium removal included: (1) over estimation of the NaTPB reagent concentration, (2) slow reaction kinetics due to high $\mathrm{Na}^{+}$ concentration, and (3) under estimation of potassium content. A redetermination of the NaTPB concentration confirmed that the value used in the calculations for the quantity of reagent to add in the test was correct.' Slow reaction kinetics is unlikely since the calculated $\mathrm{Na}^{+}$concentration prior to NaTPB addition was $4.5 \mathrm{M}$. However, the $\mathrm{Na}^{+}$concentration was not determined analytically. The most likely explanation is an underestimation of the potassium concentration. The total number of moles of potassium in the test slurry was calculated to be $2.74 \times 10^{-3}$. This number was based on on the higher average value from the analysis of tank samples and allowing for the measurement uncertainty from replicate determinations[3]. However, there could be a matrix effect in the potassium determination that results in an under estimation of the true potassium content and, therefore, the amount of NaTPB needed for precipitation.

Table 1. Total Alpha and Cs-137 Activities in ITP Batch \#2 Test Filtrates

$\begin{array}{cccc}\text { Addition \# } & \begin{array}{c}\text { Calculated } \\ \text { mole NaTPB/mole K }\end{array} & \text { Total alpha } & \text { Cstivity }(\mathrm{nCi} / \mathrm{g}) \\ 1 & 1.38 & 0.48 \pm 0.21 & 230 \pm 4 \\ 2 & 2.44 & \text { not determined } & 4.0\end{array}$

\section{References}

1. Process Requirement 241-82H Control Room (U), WSRC-IM-91-63, revision 6, January, 1996.

2. R. L. Boyleston, "Cycle I Batch 2 Composition", January 17, 1996.

3. D. T. Hobbs, “Analytical Results for ITP Batch \#2 Tank Samples”, IWT-LWP-96-0012, January 29, 1996.

c::
R. L. Boyleston, 706-23C
A. W. Wiggins, $241-84 \mathrm{H}$
G. A. Taylor, 703-H
M. D. Johnson, 703-56H
T. M. Monahon, 703-H
B. L. Lewis, 703-8C
H. D. Harmon, 719-4A
J. D. Menna, 730-2B
N. R. Davis, 719-4A
W. L. Tamosaitis, 773-A
R. A. Peterson, 676-T
W. B. Van Pelt, 676-1T
J. R. Fowler, 704-Z
D. A. Barber, 241-120H

SRT-LWP-96-0042, rev. 0
R. C. Fowler, 241-152H

P. L. Rutland, $241-152 \mathrm{H}$

B. G. Croley, 241-120H

W. C. Clark, 241-119H

J. E. Marra, 703-H

M. C. Chandler, 703-H

J. P. Morin, 719-4A

B. J. Shapiro, 241-119H

W. R. Parish, 703-8C

M. J. Barnes, 773-A

R. F. Swingle, 773-A

R. A. Jacobs, 704-T

M. Schwenker, 241-120H

A. Patterson, 773-A (LWP records) 
WSRC-TR-96-0190

Page 35 of 35

September 6, 1996

\section{Distribution:}

Amerine, D. B., 241-121H

Barnes, M. J., 773-A

Barber, D. A., 241-120H

Bibler, J. P., 773-A

Blue, D. M. , 742-6G

Boyleston, R. L., 706-23C

Britt, T. E., 732-B

Brooke, J. N., 719-4A

Butcher, B. T., 773-43A

Cardona-Quiles, O., 704-56H

Carter, J. T., 241-121H

Cauthen, G. A., 241-119H

Chandler, M. C., 703-H

Chapman, N. F., 704-99S

Christensen, A. P., 705-1C

Clark, W. C., 241-119H

Coleman, C. J., 773-A

Crawford, C. L., 773-41A

Croley, B. G., 241-120H

Cummings, R. W., 241-121H

Davis, N. R., 719-4A

Dickert, V. G., $703-\mathrm{H}$

Doughty, D. E., 241-153H

Dworjanyn, L. O., 779-2A

Eibling, R. E., 704-T

Elder, H. H., 704-S

Fink, S. D. , 773-A

Fowler, J.R. , 241-121H

Fowler, R. C., 241-152H

Griffith, R. W. , $241-153 \mathrm{H}$

Gupta, M. K., .732-B

Harmon, H. D. , 719-4A

Hobb, D. T. , 773-A

Holtzscheiter, E. W., 773-A

Hsu, C. W. , 773-A

Hyder, M. L., 773-A

Jacobs, R. A., 704-T

Jamison, M. E. , 703-H

Johnson, M. D., 704-56H

Keefer, M. T.: 241-153H

KelIy, J. L., 241-119H

Landon, L. F. 704-T

Lemay, A. , 241-121H

Miller, M. L, 241-120H
Maxime

For file noom.

Leung, C. , 241-119H

Lewis, B. L., 703-H

Lex, T. J., 719-4A

Long, B. E., 241-197H

Lott, D. E., $241-197 \mathrm{H}$

Marra, J. E., 241-120H

McCabe, D. J., 773-43A

Menna, J. D., 241-121H

Montini, M. J., 704-S

Morin, J. P., 719-4A

Murdoch, D. G., 704-56H

Norkus, J. K., 730-2B

O'Connor, J. L., 241-120H

Ortaldo, J. F., 704-S

Papouchado, L. M., 773-A

Patel, P. M., 512-11S

Peterson, R.A., 676-T

Poirier, M. R., 676-T

Rutland, P. L., 241-152H

Satterfield, R. M., 719-4A

Schwenker, M., 241-120H

Shapiro, B. J., $241-119 \mathrm{H}$

Stevens, W. E., 773-A

Stubblefield, G., 241-120H

Stubbs, W., 703-H

Suggs, P., 703-H

Swingle, R. F., 773-A

Tamosaitis, W. L., 773-A

Temple, T., 703-H

Thomas, J. K., 730-2B

Vanpelt, W. B., 676-1T

Venkatesh, S., 742-5G

Vetsch, W. J., 512-4S

Walker, B. W. , 676-T

walker, D. D. , 773-A

Walker, W. C, 241-82H

Wiggins, A. W., $241-84 \mathrm{H}$

Williams, M. R., 241-121H

Wilson, R. W. , 703-H

Wooten, A. L., 732-B

Wright, G. T., 703-H

Zupon, D. A., 730-B

IWT-LWG Files, 773-A

TIM, 703-43A 